\title{
ERP Components Associated with Syntactic Ambiguity and Word Order Canonicity in Processing Sentence with Ditransitive Verb between Young and Elderly Adults
}

\author{
Hae Mi Yoo, Jee Eun Sung \\ Department of Communication Disorders, Ewha Womans University, Seoul, Korea
}

Correspondence: Jee Eun Sung, PhD

Department of Communication Disorders, Ewha Womans University, 52 Ewhayeodae-gil, Seodamun-gu, Seoul 03760, Korea

Tel: +82-2-3277-2208

Fax: +82-2-3277-2122

E-mail: jeesung@ewha.ac.kr

Received: July 9, 2018

Revised: August 12, 2018

Accepted: August 12, 2018

This work was supported by the Ministry of Education of the Republic of Korea and the National Research Foundation of Korea (No. NRF2017R1A2B4006604).

\begin{abstract}
Objectives: The purpose was to investigate differences between young and elderly adults in event-related potentials (ERPs) associated with syntactic ambiguity and word order canonicity in processing sentences with ditransitive verbs using a verb-final language. Methods: A total of 48 participants participated in the study. A sentence comprehension task and an online ERP analysis were used. The stimuli were composed of 5 phrases such as a noun phrase 1 (nominative phrase), a noun phrase 2 (dative phrase), an adverbial phrase, a noun phrase 3 (accusative phrase), and a verb. These phrases were divided into two conditions, syntactic ambiguity and word order canonicity. Canonical word order consists of a dative phrase before an accusative phrase and non-canonical word order has the accusative phrase before the dative phrase. Syntactic ambiguity was manipulated through the deletion of object case markers. Results: Behavioral results revealed that the elderly group showed significantly lower accuracy and slower reaction time than the younger group, especially in ambiguous condition when compared with the unambiguous condition. ERP results revealed that younger adults generated $\mathrm{N} 400$ but elderly adults generated P600 for noun phrase 3 in ambiguous sentences. Younger adults generated P300 in canonical sentences and greater negativity in non-canonical sentences for noun phrase 2 in the ambiguous condition. Conversely, elderly adults generated similar sentence processing patterns in both canonical and non-canonical sentences. Discussion: The results indicated that processing patterns for syntactic ambiguity and word order canonicity in ditransitive sentences are significantly different between two groups. The elderly adults' ERP processing feature could be an attribute of age-related language changes.
\end{abstract}

Keywords: ERP, Sentence with ditransitive verb, Syntactic ambiguity, Word order canonicity, Aging, Sentence processing
우리나라 노인 인구의 비율이 점차적으로 증가하고 있다. 우리나 라 65세 이상의 인구는 2016년 699만 명으로 전체 인구의 $13.5 \%$ 에 이르렀다. 또한 노인비율은 점차 증가하여 2060년에는 1,762 만 명 으로 $40.1 \%$ 로 10 명 중 4 명 이상이 노인이 되는 비율에 달할 것으로 추정된다(Statistics Korea, 2017). 노인 인구가 증가함에 따라 사회 전반에서 노인의 건강과 질환에 대한 관심이 높아지고 있으며, 노 화로 인한 신체적 기능의 저하뿐만 아니라 인지기능 및 언어능력의
저하에 대한 예방과 치료가 필요하다는 인식이 높아지고 있다 (Ministry of Health and Welfare, 2012). 다양한 연구자들이 신경 학적 질환의 초기 증상에서 나타날 수 있는 언어적 손상 특징이 정 상 노화와는 구분된다는 결과를 보고하고 있다(Bayles, Tomoeda, \& Trosset, 1990; Chertkow \& Bub, 1990; Lee \& Kim, 2011). 따라서, 정상적인 노화에 따른 언어능력 감퇴 현상을 이해하고자 하는 노 력은 병리적인 현상의 조기 발견에 매우 중요한 역할을 할 수 있으 
며, 이러한 언어손상 지표가 경도인지장애 및 치매와 같은 퇴행성 질환을 예측하는 변인이 될 수 있는지에 대한 관심이 높아지고 있 다. 다양한 언어손상 특징 중, 노화에 따른 문장처리능력 감퇴에 대 한 연구가 행동반응 측정부터 사건관련전위(event-related brain potentials, ERP), 기능적 자기공명영상법(functional magnetic resonance imaging, fMRI), 안구추적(eye-tracking) 등의 기술을 활 용하여 보고되고 있다(Grossman et al., 2002; Kemmer, Coulson, De Ochoa, \& Kutas, 2004; Kim, Sung, Lee, \& Sim, 2018; Stine-Morrow et al., 2010).

문장처리 연구가 노화와 관련된 언어손상 진단에서 주목을 받 고 있는 이유로는 문장처리 과정이 단어수준에 비해 문법적으로 더 복잡한 처리과정을 포함하고 있기 때문이다(Ferreira \& Cokal, 2015; Friederici, 2011). 따라서 문장처리 과정이 지니고 있는 복잡 성이 노화를 예측하는 데 더 민감할 수 있다는 측면에 주목하여 다 양한 연구가 진행되고 있다(Caplan, DeDe, Waters, Michaud, \& Tripodis, 2011; Stine-Morrow, Ryan, \& Sandra Leonard, 2000; Zurif, Swinney, Prather, Wingfield, \& Brownell, 1995). 특히, ERP를 통해 실시간으로 문장처리 과정을 분석하는 방법은 노화로 인한 미묘한 언어적 변화를 보기에 적합하다고 보고되어 왔으며(Kaan, 2007; Kemmer et al., 2004), 국내에서도 다양한 문장 유형을 대상 으로 노년층의 문장처리 손상을 알아보기 위해 ERP 분석방법을 적용해오고 있다. 현재까지 보고된 문장 유형으로는 한국어에 특 징적으로 나타나는 경어법 사용에 대한 연구(Oh \& Sung, 2017)에 서부터, 피동형 구문 연구(Yoon, 2015), 명사구의 생물성 여부(Cheon, 2016), 격조사 처리 양상(Paek, 2017), 동음이의어 처리 양상(Jo \& Sung, 2018), SVO (Subject-Verb-Object) 구문에서의 어순전형성 (Oh, Sung, \& Sim, 2016)에 이르기까지 다양하게 노년층 ERP 연구 가 시도되고 있다. 본 연구에서는 이러한 다양한 문장 유형 중에서 도 수여동사구문에서의 어순전형성 및 통사적 중의성을 조작하여 노년층 문장처리 과정을 $\mathrm{ERP}$ 를 적용하여 살펴보고자 한다.

문장처리에서 중요한 역할을 하는 통사적 요소 중 하나로 어순 (word order)에 대해 다양하게 연구되어 왔다. 어순은 문장처리 과 정에서 의미역을 할당하고 구문구조를 예측하는 데 중요한 단서를 제공하여 문장이해에 영향을 끼치는 것으로 보고되었다(Tamaoka et al., 2005). 주로 어순에 대한 연구는 어순전형성(canonicity)에 따른 영향을 다수의 연구에서 보고하고 있다(Hagiwara, Soshi, Ishihara, \& Imanaka, 2007; Matzke, Mai, Nager, Rüsseler, \& Münte, 2002). 어순전형성은 타동사 구문을 대상으로 다양한 언어에서 연 구되고 있다. 문장 어순이 비교적 자유로운 독일어와 일본어에서 어순전형성에 대한 ERP 및 fMRI 연구가 보고되었다. 독일어 사용
자 정상 성인을 대상으로 주어가 선행하는 전형 어순 구문과 목적 어가 선행하는 비전형 어순의 타동사 문장구문을 처리하는 동안 fMRI로 뇌를 촬영한 결과, 비전형 어순을 처리할 때, 좌측 하위 전 두엽의 브로카 영역이 활성화되었으며, 문장판단과제의 정확도도 유의하게 낮게 나타났다. 이러한 결과는 비전형 문장구조를 처리 하는 데 언어적 능력과작업기억능력에 대한 요구가 상대적으로 높 아지는 것에 기인하는 것으로 해석하였다(Bahlmann, RodriguezFornells, Rotte, \& Münte, 2007). 일본어 사용자 정상 성인을 대상 으로 주절과 종속절 모두 주어가 선행하는 전형적인 문장과 종속 절 내 목적어가 선행하는 국지적(middle) 비전형 문장, 주절의 주어 와 종속절의 주어와 목적어의 순서가 모두 변경된 전역적(long) 비 전형 문장처리 패러다임을 문장판단과제 및 $\mathrm{ERP}$ 분석을 적용하여 연구하였다. 그 결과, 문장판단과제에서 전역적 비전형 문장에서 수행력이 가장 저조하였으며, ERP 성분에서는 sustained anterior negativity (SAN)와 P600이 나타났다. 국지적 비전형 문장과 전역 적 비전형 문장읽기 중에도 전두엽 전극 양쪽에서 부적 전위 성분 이 발생하여, 비전형 문장처리가 전형 문장처리에 비해 부담이 되 는 어순전형성 효과를 나타내는 것으로 확인되었다(Hagiwara et al., 2007).

한국어 또한 문장 어순이 비교적 자유로운 자유어순언어(free word-order language)에 속하며, 동사가 문장 마지막에 오는 동사 후치어(head-final language) 특징을 지닌다(Im, 2007). 이러한 특 징에 착안하여 Sung (2015)은 SOV 어순을 가진 타동사 문장의 전 형(SOV) 및 비전형(OSV) 어순의 목표문장을 들려주고 두 가지 그 림 중 문장과 일치하는 그림을 선택하는 과제를 실시하였는데, 그 결과 비전형 어순에서 전형 어순에 비해 문장이해과제에서 수행력 이 저하되었다고 보고하였다. Oh 등(2016)은 ERP를 사용하여 타 동사 문장을 전형 문장과 비전형 문장으로 구분하여 하나는 주어 가 선행하는 문장으로, 다른 하나는 목적어가 선행하는 문장으로 실험문장을 구성하여 문장이해과제 및 ERP 연구를 실시하였다. 비전형 문장인 OSV 문장에서 정확도가 낮아지고 반응시간이 지 연되는 현상이 나타났다. 또한, ERP 성분 분석에서는 비전형적 어 순의 문장처리 시 left anterior negativity (LAN) 효과가 나타나는 것으로 보고되었다. 이러한 결과를 통해 저자들은 한국어의 비전 형 문장에서도 어순전형성 효과가 나타난다는 것을 밝혔다.

이처럼 국내에서도 문장처리 과정에서 나타나는 어순전형성 효 과를 행동분석 방법이나 ERP 분석방법으로 밝히려고 시도한 것으 로 확인되지만, 한국어 수여동사구문에 대한 ERP 연구는 아직 전 무하다. 수여동사구문의 어순전형성에 대해 독일어권에서 연구가 보고되었다. 독일어에서의 수여동사구문의 전형 어순을 Subject- 
Indirect Object-Direct Object-Verb (S-IO-DO-V, 주어-여격어-대 격어-동사)로 정의하고, S-DO-IO-V를 포함한 다섯 가지 비전형 문 장으로 설계하여 어순전형성 효과를 $\mathrm{ERP}$ 를 통해 알아보았다. 그 결과, 여격어 선두 문장(IO-x-x), 대격어 선두 문장(DO-x-x), 주어 다음에 위치하는 명사구가 대격어인 문장(S-DO-x), 총 세 가지 조 건의 비전형 문장에서 격조사 다음에 일시적인 LAN이 나타나 수 여동사구문 문장에서의 어순전형성 효과가 보고되었다.

본 연구에서의 한국어 수여동사구문 연구는 "-가(주어) -에게 (여격어) -를(대격어)”의 서술구조를 취하는 동사구문을 수여동사 구문이라 정의하였으며(Hwang, 2003), 수여동사구문 문장의 어순 전형성은 여격어 선행 어순을 전형어순, 대격어 선행 어순을 비전 형 어순이라는 연구를 근거로 하여(Im, 2007; Kim, 2002; Shin, 2007) 수여동사구문의 전형 문장은 여격어 선행 어순 문장으로, 비전형 문장은 대격어 선행 어순 문장으로 설계하여 어순전형성에 따른 반응을 살펴보고자 하였다.

어순전형성 외에도 문장처리에서 관심 있게 연구되고 있는 요소 로 통사적 중의성(syntactic ambiguity)을 들 수 있다. 통사적 중의 성이란 통사적 해석이 일시적으로 애매한 문장으로 문법적으로 오 류와는 구별된다. 통사적 중의 문장 이해 과정을 살펴보는 것은 의 미 영역, 구문 영역 등 여러 언어 영역에서의 정보처리, 정보저장 및 문장 정보의 의미를 계산하고 통합하는 과정이 어떻게 이뤼지는지 확인할 수 있다는 점에서 연구자들의 관심사가 되어왔다(Bahlmann et al., 2007; Kaan \& Swaab, 2003). 영어권에서는 주로 오인문장 (garden-path sentence) 읽기과제에 대한 행동분석 또는 안구 움직임 분석을 통한 연구가 실시되었다.

Frazier와 Rayner (1982)의 연구에서는 캐나다인 정상 성인을 대 상으로 두 개의 절로 구성된 오인문장들을 제시하여 읽기처리 과정 을 안구 움직임으로 분석하였다. 문장은 길이(단문장 또는 장문장) 와 동사다음에 제시되는 명사구의 역할(첫 번째 절의 목적어 "Since Jay always jogs a mile this seems like a short distance to him." 또는 두 번째 절의 주어 "Since Jay always jogs a mile seems like a very short distance to him.")을 달리하였다. 최소 부착(minimal attachment) 전략에 의해 동사 이후에 제시된 명사구를 동사의 목적어로 해석하게 될 것이며, 명사구가 첫 번째 절의 목적어가 아닌 두 번째 절의 주어일 경우 통사적 해석이 일시적으로 애매해지도록 설계하 였다. 그 결과, 명사구가 두 번째 절의 주어가 되는 중의적 문장에서 읽기 시간이 오래 걸렸으며, 단문장에 비해 장문장에서 지연되었다. 영어권의 오인문장 형태와는 달리 독일어, 일본어, 바스크어(Basque), 한국어와 같이 비교적 자유로운 어순과 격조사를 가진 언어권에서 주로 격조사를 조작(manipulation)하여 통사적 중의성을 연구하였
다. Erdocia, Laka, Mestres-Missé과 Rodriguez-Fornells (2009)의 $\mathrm{ERP}$ 연구에선 SOV 문장을 구성하는 주어와 목적어의 격조사를 모두 격(case)과 상관없이 동일하게 조작한 후, 중의 문장과 비중의 문장처리 과정을 살펴보았다. 또한 중의 문장을 전형 문장과 비전 형 문장으로 구분하여 중의 조건에서의 어순전형성 효과를 함께 살펴보았다. 그 결과 중의 문장의 동사에서 통사적 중의성 해결 과 정 중에 발생하는 것으로 알려진 P600 성분이 나타났으며 정확도 가 저하되었다. 중의 문장을 전형 문장과 비전형 문장으로 구분하 여 살펴본 실험결과에서도 비전형 문장의 통사적 중의성이 해결되 는 동사구간에서 문장처리 부담이 가중될 때 나타나는 전두엽 부 적전위가 발생하였다. 저자는 이를 '전형어순 처리 이점'에 의해 중 의 조건에서도 전형 어순에 비해 비전형 어순 문장에서 문장처리 부담이 증가된다고 해석하였다. 국내에서도 $\mathrm{Oh}$ 등(2016)이 한국인 정상 청년층과 노년층을 대상으로 한국어 SOV 문장 내 격조사를 생략한 중의 문장을 활용한 ERP 연구를 실시하였다. 중의 조건에 서의 어순전형성 효과를 알아보기 위해서 전형 어순(SOV) 문장에 서는 주격 조사를, 비전형 어순(OSV) 문장에서는 목적격 조사를 각각 생략하여 실험하였다. ERP 양상을 비교한 결과, 비전형 어순 문장의 목적어 구간에서 P600 성분이 관찰되었다. 이는 초기 문장 처리 시 전형 어순이 적용되어 격조사가 생략된 선행 명사구를 주 어로 해석하였다가, 뒤이어 제시된 명사구의 격조사가 주격인 것을 인식하면서 선행 명사구를 다시 목적어로 수정하여 해석하는 과정 에서 P600이 나타난 것으로 보고되었다. 하지만 아직 국내에서는 중의 조건에서의 어순전형성에 따른 문장처리와 비중의 조건에서 의 어순전형성에 따른 문장처리 간의 비교가 실시되지 않았으며, 수여동사구문 문장에 대한 통사적 중의성 연구는 시도된 바가 없 다. 따라서 본 연구에서 통사적 중의성은 수여동사구문 문장에서 두 번째 명사구와 세 번째 명사구, 즉 여격어와 대격어의 격조사를 모두 생략하는 방식으로 설계하여 통사적 중의성 여부 및 어순전형 성에 따른 행동 및 $\mathrm{ERP}$ 반응을 살펴보고자 하였다.

본 연구에서는 청년층과 노년층 대상으로 수여동사구문 문장처 리 과정을 $\mathrm{ERP}$ 를 통한 뇌파 분석과 행동분석을 통해 살펴봄으로 써, 문장처리에 나타나는 통사적 중의 처리와 어순전형성 양상이 노화를 발견할 수 있는 주요한 언어변수가 될 수 있는지, 병리적으 로는 어떤 의미를 가질 수 있는지에 대해 알아보고자 한다. 본 연구 의 구체적인 연구질문과 가설은 다음과 같다.

첫째, 중의성 여부(중의 vs. 비중의) 및 수여동사구문의 어순전형 성(전형 vs. 비전형)에 따라 문장판단과제의 정반응률 및 반응시간 에서 정상 청년층 및 노년층 간 차이가 유의한가? 본 연구 질문에 대한 가설 및 이론적 배경에 근거한 예측 결과는 노년층의 경우, 수 
여동사구문 문장이 중의적일 때와 비전형 어순일 때 청년층에 비 해 문장처리의 어려움이 증가할 것으로 예상하며, 중의 조건 및 비 전형 어순 문장에서 저조한 정반응률과 지연된 반응시간이 관찰되 는지를 중점적으로 살펴보고자 한다.

둘째, 중의성 여부(중의 vs. 비중의) 및 수여동사구문의 어순전형 성(전형 vs. 비전형)에 따라 ERP 평균진폭(mean amplitude) 크기 에서 정상 청년층 및 노년층 간 차이가 유의한가? 본 연구질문에 대 한 가설은 비중의 조건에 비해 중의 조건에서 어순전형성에 따라 청년층과 노년층이 발생시키는 ERP 성분들이 다른 양상을 보일 것 으로 예상하며, 각 집단별로 나타난 ERP 성분 및 평균진폭 크기를 중점적으로 살펴보고자 한다.

\section{연구방법}

\section{연구대상}

본 연구는 정상 청년층 25 명과 정상 노년층 25 명, 총 50 명을 대상 으로 진행하였다. 청년층은 만 20-40세, 노년층은 만 60-80세로 연 령을 구분하였다. 노년층의 연령 기준은 고령자고용촉진법, 노인복 지법, 국민기초생활보장법상에서 규정하는 노인 연령의 평균을 구 하여 60 세 이상으로 선정하였다.

모든 대상자는 (1) 모국어가 한국어, (2) 교육년수가 12년 이상으 로 청년층과 노년층 간 교육년수에서 유의한 차이가 없도록 일치시 켰으며 $\left(F_{(1,46)}=3.724, p>.05\right)$, (3) 시력 혹은 교정시력이 정상이며, (4) 언어 및 인지발달에 문제가 없는 자로, (5) 건강선별설문지(Health Screening Questionnaire; Christensen, Multhaup, Nordstrom, \& Voss, 1991)상 신경학적 손상 및 정신적 병력이 없으며, (6) 한국형 간이정신상태검사(Korean version of Mini-Mental State Examination, K-MMSE; Kang, Na, \& Hahn, 1997)와 한국웩슬러 성인용 지능검사의 숫자 바로 따라하기와 거꾸로 따라하기 검사(forward and backward digit span) (Korean-Wechsler Adult Intelligence Scale, K-WAIS; Yum, Park, Oh, Kim, \& Lee, 1992)상 결과가 연령 및 교육수준에 따라 정상범위 $16 \%$ ile 이상에 속하는 자로 선정하 였다. 정상 노년층 집단은 추가적으로 서울언어학습검사(Seoul Verbal Learning Test, SVLT; Kang \& Na, 2003)에서 결과가 정상범위 $16 \%$ ile 이상에 속하는 자로 선정하였다.

선정된 이들을 대상으로 실험을 진행한 후, 데이터 분석과정에 서 기타잡음(artifacts) 등을 제거하고 $70 \%$ 이상의 조건이 남아있는 청년층 24 명(여성 17 명, 남성 7명; 평균연령 28.33세, 표준편차 4.86) 과 노년층 24 명(여성 15 명, 남성 9명; 평균연령 63.92세, 표준편차 4.07)의 데이터를 최종적으로 사용하였다. 집단별 대상자 정보는
Table 1. Descriptive information on participants

\begin{tabular}{lcc}
\hline & Young group ( $\mathrm{N}=24)$ & Elderly group (N=24) \\
\hline Gender & & \\
Male & 7 & 9 \\
Female & 17 & 15 \\
Age (yr) & $28 \pm 5(20-37)$ & $64 \pm 4(60-74)$ \\
Education (yr) & $16 \pm 2(12-18)$ & $15 \pm 2(12-18)$ \\
K-MMSE score & $30 \pm 1$ & $29 \pm 1$ \\
SVLT score & - & $76 \pm 18$
\end{tabular}

Values are presented as mean \pm SD (range).

K-MMSE = Korean version of Mini-Mental State Examination; SVLT=Seoul Verbal Learning Test.

Table 1에 제시하였다. 집단별 교육년수가 통계적으로 유의한 차이 가 있는지 알아보기 위해 일원배치분산분석(one-way ANOVA)을 실시하였으며, 그 결과 두 집단의 교육년수는 통계적으로 유의한 차이가 없었다 $\left(F_{(1,46)}=3.724, p>.05\right)$.

\section{실험과제}

실험자극

총 180 개의 실험문장을 구성하였다(목표문장 120 개, 메꿈문장 60 개). 모든 실험문장은 5 개의 어절로 이루어지며, 목표문장은 첫 번째 명사구(이하 명사구1), 두 번째 명사구(이하 명사구2), 부사구, 세 번째 명사구(이하 명사구3), 동사로 구성하였다. 명사구1은 주어 이며, 명사구 2 와 명사구 3 은 조건에 따라 여격어 또는 대격어가 된 다. Hwang (2003) 연구의 목록에서 수여동사를 선정하되, 수여동 사의 4 가지 형태인 단일동사 형태 중 원형적 수여동사, '-하다' 파생 동사 형태, 합성동사 형태, 사동사 형태 중에서 합성동사 및 사동사 형태는 문장이해에 영향을 줄 수 있으므로 제외시키고, 단일동사 형태와 '하다' 파생동사 형태를 사용하였다. 또한 수여동사의 의미 적 특징은 크게 기본의미와 주변의미로 나눌 수 있으나, 본 연구에 서는 '대상의 이동'이란 기본의미를 가진 동사를 사용하였다. 주어 는 행위주로 가족 명사를 사용하였다. 대격어는 행위주로부터 수 혜주에게 이동하는 구체물 또는 추상적 대상물이 되는 명사를 사 용하되, 현대국어사용빈도조사(National Institute of Korean Language, 2005) 및 꼬꼬마 세종 말뭉치 활용시스템상에서 빈도 1,000 이상의 고빈도 어휘를 선정하였다. 여격어는 행위주가 이동시킨 대 상물을 받는 수혜주로 Nam (2014)의 실험문장에서 사용한 일반적 인 사람이름을 사용하였다. 부사어는 어제 오후에, 오늘 아침에 등 15 개의 시간관련 부사로 한정하며, 중복사용 횟수를 2 회로 통제하 였다. 대상자가 실험의도를 파악함으로써 검사가 왜곡되는 것을 막 기 위하여 60 개의 메꿈문장 자극을 추가하였으며, 실험문장과는 
다른 형태의 다양한 문장들로 구성하였다.

명사구 2 와 명사구 3 의 격조사를 모두 생략하는 방식으로 통사 적 중의성을 조절하여 비중의 문장과 중의 문장으로 구분하였으 며, 각각 60 개 실험문장으로 구성하였다. 비중의 문장은 한국어 수 여동사구문 전형(주어+여격어+부사어+대격어+동사)과 비전형 (주어+대격어+부사어+여격어+동사), 2가지 유형으로 분류하여, 각 조건당 30 문장씩 구성하였다. 중의 문장은 명사구 2 와 명사구3 의 격조사가 모두 생략된 전형어순 문장과 명사구 2 와 명사구 3 의 격조사가 모두 생략된 비전형 어순 문장인 2가지 유형으로 분류되 며, 각 조건당 30 문장씩 구성하였다. 분석을 위한 실험단어(critical word)는 명사구2, 명사구3, 동사구로 하였다. 실험단어가 제시되기 $200 \mathrm{~ms}$ 전부터 제시되고 난 후 $900 \mathrm{~ms}$ 까지를 분석대상으로 삼았 다. 본 연구의 실험자극의 예를 Table 2에 제시하였다. 한국어의 영 어표기는 Yale Romanization System (Martin, 1992)을 사용하였다. 실험 자극 문장은 Appendix 1에 제시하였다.

\section{문장판단과제}

피험자들은 24 인치 LCD 모니터의 앞에 편안하게 앉은 후, 모니 터에 제시되는 문장을 읽고 문장판단과제를 수행하였다. 문장 제 시는 실험용 소프트웨어인 이-프라임(E-Prime 2.0; Psychology Software Tools, Sharpsburg, PA, USA)을 이용하여 진행하였다. 본 실험 전 7개의 연습 문장을 진행하여 피험자들이 실험에 자연스럽 게 적응하도록 유도하며 즉각적인 피드백을 제시하여 과제수행 방 법을 숙지시켰다. 총 180 개의 문장이 의사 무작위 방식(pseudo-randomized)으로 제시되며, 자극은 총 3 세트로 나누어 60 문장씩 실 시하였다.

실험자극 제시 과정은 우선 '+’ 표시(fixation)가 $500 \mathrm{~ms}$ 동안 화 면 가운데에 나타나 피험자의 시선을 고정시킨 후, 어절별로 모니 터 중앙에 제시되었다. 한 어절의 제시 시간은 $700 \mathrm{~ms}$, 어절 간 빈 화면은 interstimulus interval (ISI)로 $200 \mathrm{~ms}$ 로 통일시켰다. 문장 의 각 어절이 제시되고 나면, 전체 문장이 $3,000 \mathrm{~ms}$ 제시되고, 이어 서 문장판단과제로 문장에 대한 질문이 $5,000 \mathrm{~ms}$ 제시되었다. 질문

Table 2. Examples of sentence stimuli for each condition

\begin{tabular}{lcl}
\hline Syntactic ambiguity & Word order canonicity & \multicolumn{1}{c}{ Examples of sentence stimuli } \\
\hline Unambiguous & Canonical & Mom-Nom. MinSoo-Dat. yesterday evening milk-Acc. give-past.dec. \\
& Non-canonical & Emma-ka minswu-eykey ecey ohwuey wuyu-lul cwu-esst-ta. \\
& Mom-Nom. milk-Acc. yesterday evening MinSoo-Dat. give-past.dec. \\
Canonical & Emma-ka wuyu-lul ecey ohwuey minswu-eykey cwu-esst-ta. \\
& Mom-Nom. MinSoo yesterday evening milk give-past.dec. \\
& Emma-ka minswu ecey ohwuey wuyu cwu-esst-ta. \\
& Nom- canonical & Mom-Nom. milk yesterday evening MinSoo give-past.dec.
\end{tabular}

The bold and italicized words are critical words.

Nom= nominative; Dat $=$ datative; $A c c=$ accusative; dec $=$ declarative .

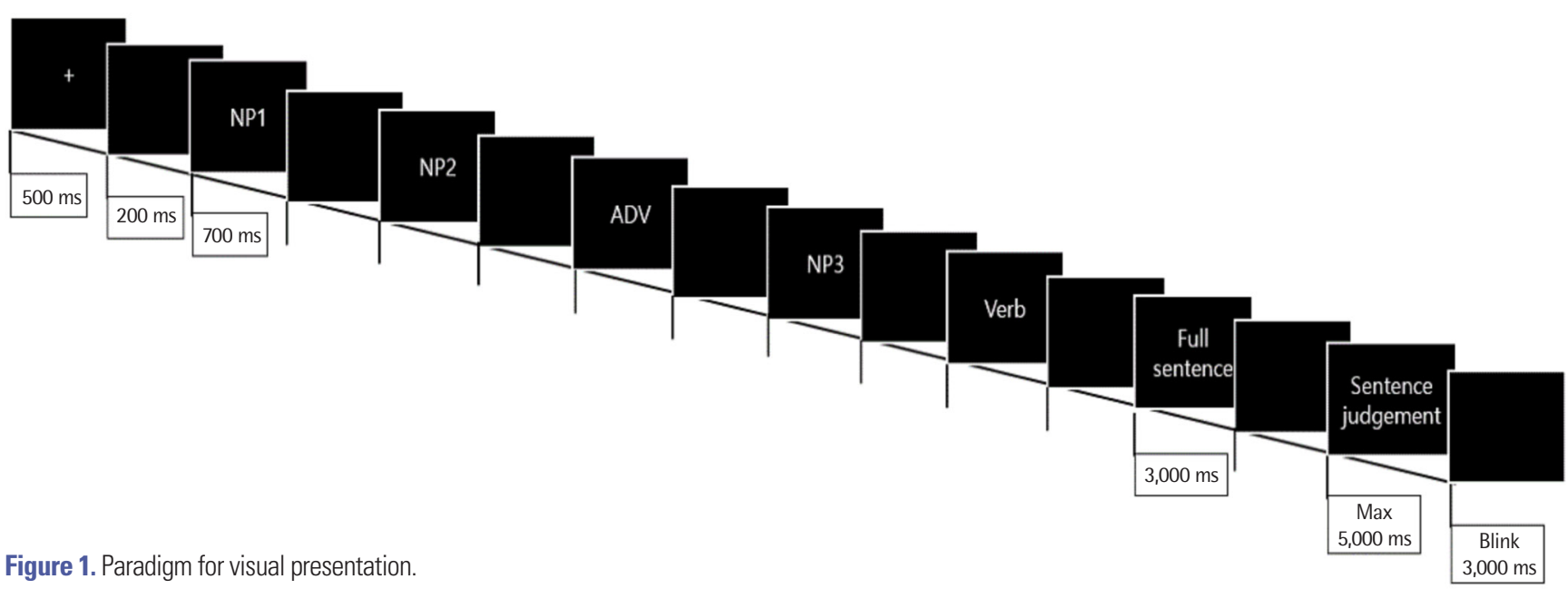


이 제시되는 시간 동안 피험자들은 직전에 제시된 문장의 내용을 생각하여 정/오 판단을 수행하였다. 답변이 '맞다'이면 파란색 버튼 을, '틀리다’이면 빨간색 버튼을 누르도록 하였다.

문장판단과제의 질문은 Rösler, Pechmann, Streb, Röder와 Hennighausen (1998) 연구를 참고하여 의미역들 간의 관계를 묻는 내 용으로 구성하였다. 2 가지 유형으로 구분하여 주어와 대격어의 관 계, 여격어와 대격어의 관계를 질문하였으며, 맞다와 틀리다 답변의 개수가 동일하도록 구성하였다. 자극 제시 절차는 Figure 1에 제시 하였다.

\section{ERP 실험}

본 실험은 소음 및 전자파 쉴드룸(soundproof and electrically shield room)에서 실험이 진행되었으며, Brain Products사의 BrainAmp Standard와 actiCAP을 사용하여 EEG를 기록하였다. 피험자 의 두피에 은/염화은 전극을 국제표준방식인 10-20 시스템(Jasper, 1958)에 따라 Fp1, Fp2, F7, F3, Fz, F4, F8, FC5, FC1, FC2, FC6, T7, C3, C2, C4, T8, TP9, CP5, CP1, CP2, CP6, TP10, P7, P3, Pz, P4, P8, $\mathrm{O} 1, \mathrm{O} 2$ 총 29개 부위에 부착하였다. 분석에 포함된 전극은 Midline (Fz, Cz, Pz), Left Anterior (FP1, F3, FC5, FC1, F7), Left Posterior (CP5, CP1, P7, P3, O1), Right Anterior (FP2, F4, FC2, FC6, F8), Right Posterior (CP2, CP6, P4, P8, O2)이다. 실험 중 나타나는 눈 깜박임 을 탐지하기 위해 오른쪽 눈 밑 약 10-15 mm에 1개의 전극을 부착 하여 안전도(electrooculogram)를 측정하였고, 2 개의 기준전극 (reference electrodes)은 피험자의 좌우 유양돌기(mastoids)에 각각 부착하였다. EEG 기록 중에 발생하는 전극 저항은 $10 \mathrm{k} \Omega$ 이하로 유지하고, 전체 EEG 데이터는 $500 \mathrm{~Hz}$ 로 샘플링 하였다. 피험자들 에게 실험 시작 전에 실험에 관한 지시 사항을 먼저 읽도록 하며, 뇌 파를 측정하는 동안 몸의 움직임과 눈 깜빡임을 최소화하도록 주 의시켰다. 실험 시 쉴드룸(shield room) 내부는 소등되었으며, 24인 치 모니터만 켜진 상태에서 피험자는 과제를 수행하였다.

Table 3. Descriptive statistics of accuracy (\%) on the sentence judgement task as a function of syntactic ambiguity and word order canonicity for each group

\begin{tabular}{llcc}
\hline Syntactic ambiguity & $\begin{array}{c}\text { Word order } \\
\text { canonicity }\end{array}$ & $\begin{array}{c}\text { Young } \\
(\mathrm{N}=24)\end{array}$ & $\begin{array}{c}\text { Elderly } \\
(\mathrm{N}=24)\end{array}$ \\
\hline Unambiguous & Canonical & $95.42 \pm 4.48$ & $89.44 \pm 12.92$ \\
& Non-canonical & $95.14 \pm 7.02$ & $90.56 \pm 11.57$ \\
\multirow{3}{*}{ Ambiguous } & Canonical & $95.28 \pm 5.64$ & $89.58 \pm 8.53$ \\
& Non-canonical & $95.97 \pm 5.56$ & $84.86 \pm 14.18$ \\
\hline
\end{tabular}

Values are presented as mean \pm SD.

\section{연구절차 및 자료 분석}

문장판단과제의 정반응률은 피험자가 정반응한 목표문장수를 전체 목표문장수로 나누어 백분율(\%)로 산출하였다. 피험자가 정 반응한 문항에 대해서만 분석하였다.

반응시간은 밀리세컨드 $(\mathrm{ms})$ 단위로 측정하였으며, 화면에 문장 판단과제의 질문이 제시된 순간부터 피험자가 판단하여 버튼을 누 르기까지의 시간을 측정하였다. E-Prime을 통해 측정되었으며, 반 응시간은 피험자가 정반응한 문항들에 대해서만 분석되었다.

수집된 EEG 데이터를 MATLAB R2013b와 EEGLAB 14.1.1.b 프 로그램을 이용하여 분석하였다. 피험자들이 정반응한 시행들만 선 택한 후, $250 \mathrm{~Hz}$ 로 다시 샘플링(down-sampling)하였다. 실험단어 (critical word)가 제시되기 전 $200 \mathrm{~ms}$ 동안 얻어진 값을 기초선으로 하여 자극이 제시된 후 $900 \mathrm{~ms}$ 까지 총 $1,100 \mathrm{~ms}$ 동안의 구간을 잘 랐다. 인지작용과 관련된 뇌파 범위인 $0.1-30 \mathrm{~Hz}$ 로 대역 여파 필터 (band-pass filter)를 적용하고, 눈 깜빡임을 제거하기 위해 remove $\mathrm{ICA}$ 를 실시하였다. 이후 기타 잡음을 없애기 위해 $\pm 50 \mu \mathrm{V}$ 를 넘는 시행들은 제거하였다. 이러한 과정을 거친 후 남은 시행들을 조건 별로 추출하고 평균화하여 각 집단의 평균 $\mathrm{ERP}$ 파형을 구하였다.

본 연구의 첫 번째 질문인 정상 청년층과 정상 노년층 간 중의성 여부 및 수여동사구문의 어순전형성에 따른 정반응률 및 반응시 간의 차이가 유의한지 알아보기 위하여 삼원혼합분산분석(threeway mixed ANOVA)을 실시하였다. 두 번째 연구문제인 두 집단 (청년층, 노년층) 간 중의성 여부 및 수여동사구문의 어순전형성에 따른 ERP 평균진폭의 크기가 유의한 차이를 보이는지 알아보기 위해 오원혼합분산분석(five-way mixed ANOVA)을 실시하였다. 또한, 집단별 계획분석(planned comparison)을 위해 각 집단별로 사원혼합분산분석(four-way mixed ANOVA)을 실시하였다. 통계적 분석은 SPSS version 23 (IBM, Armonk, NY, USA)을 사용하였다.

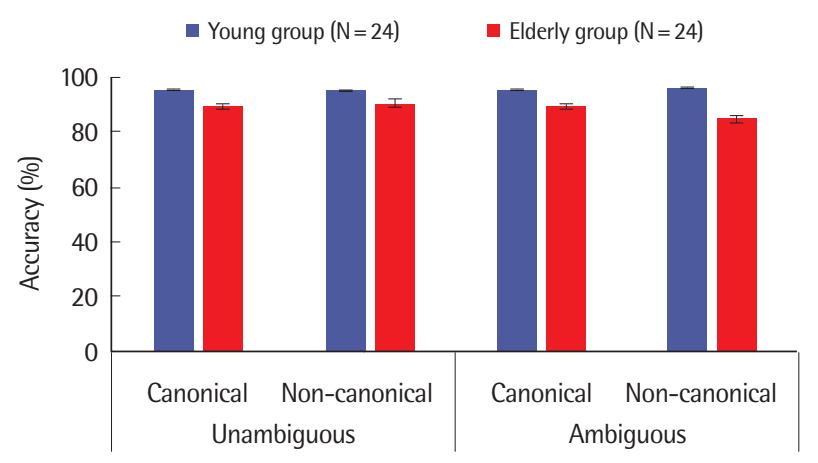

Figure 2. Accuracy on the sentence plausibility judgment task as a function of syntactic ambiguity and word order canonicity for each group (error bar is based on standard error). 


\section{연구결과}

\section{정반응률}

중의성 여부 및 수여동사구문의 어순전형성에 따른 집단 간 문 장판단과제에 대한 정반응률 차이를 알아보기 위해 집단(청년층, 노년층), 중의성(중의, 비중의), 전형성(전형, 비전형)을 독립 변인, 문장판단과제의 정반응률을 종속 변인으로 하는 삼원혼합분산분 석(three-way mixed ANOVA)을 실시하였다. 중의성 및 어순전형 성에 따른 집단별 정반응률과 표준편차는 Table 3과 Figure 2에 제 시하였다.

중의성 여부 및 수여동사구문의 어순전형성에 따른 문장판단과

Table 4. ANOVA results from the accuracy on the sentence comprehension task

\begin{tabular}{lrrrr}
\hline Distributed source & $\begin{array}{r}\text { Sum of } \\
\text { squares }\end{array}$ & $\begin{array}{c}\text { Degree of } \\
\text { freedom }\end{array}$ & $\begin{array}{r}\text { Mean } \\
\text { square }\end{array}$ & $F$ \\
\hline Between factor & & & & \\
$\quad$ Group & $2,245.891$ & 1 & $2,245.891$ & $8.355^{* *}$ \\
$\quad$ Error & $12,364.699$ & 46 & 268.798 & \\
Within factor & & & & \\
Canonicity & 30.613 & 1 & 30.613 & 1.391 \\
$\quad$ Canonicity $\times$ Group & 48.669 & 1 & 48.669 & 2.211 \\
Error & $1,012.384$ & 46 & 22.008 & \\
Ambiguity & 70.891 & 1 & 70.891 & 1.655 \\
$\quad$ Ambiguity $\times$ Group & 117.188 & 1 & 117.188 & 2.736 \\
Error & $1,970.255$ & 46 & 42.832 & \\
Canonicity $\times$ Ambiguity & 70.891 & 1 & 70.891 & 3.607 \\
Canonicity $\times$ Ambiguity $\times$ Group & 138.947 & 1 & 138.947 & $7.070^{*}$ \\
Error & 904.051 & 46 & 19.653 & \\
\hline
\end{tabular}

${ }^{*} p<.05,{ }^{* *} p<.01,{ }^{* * *} p<.001$.
제의 정반응률에서 집단에 대한 주효과가 통계적으로 유의하였다 $\left(F_{(1,46)}=8.355, p=0.006\right)$. 즉, 노년층의 정반응률이 청년층의 정반 응률에 비해 유의하게 낮았다. 또한, 전형성, 중의성, 집단 간 삼차 상호작용이 통계적으로 유의하게 나타났다 $\left(F_{(1,46)}=7.070, p=0.011\right)$. 이에 따른 사후검증으로 집단별로 전형성 및 중의성에 따른 정반 응률 변화를 살펴보기 위해 집단별 이원반복측정분산분석(twoway repeated ANOVA)을 실시하였다. 그 결과, 청년층에서는 전형 성 및 중의성에 대한 이차상호작용이 유의하지 않았지만 $\left(F_{(1,23)}=\right.$ $0.580, p=0.454)$, 노년층에서는 전형성 및 중의성에 대한 이차상호 작용이 유의하였다 $\left(F_{(1,23)}=6.914, p=0.015\right)$. 즉, 노년층은 중의 조건 일 때 전형 문장과 비전형 문장 간의 정반응률 차이가 비중의 조건 에서 전형 문장과 비전형 문장 간의 정반응률 차이 비해 유의하게 컸다. 이에 삼차상호작용은 중의 조건일 때, 비중의 조건일 때에 비 해 전형성 간의 정반응률 차이가 더 큰 것으로 나타났으며, 이는 노 년층에서만 유의하게 나타난 것에서 기인한 것으로 확인되었다. 중 의성 여부 및 수여동사구문의 어순전형성에 따른 집단 간 문장판 단과제의 정반응률에 대한 분산분석 결과는 Table 4 에 제시하였다.

Table 5. Descriptive statistics of reaction time (ms) on the sentence comprehension task as a function of syntactic ambiguity and word order canonicity for each group

\begin{tabular}{llcc}
\hline Syntactic ambiguity & $\begin{array}{c}\text { Word order } \\
\text { canonicity }\end{array}$ & $\begin{array}{c}\text { Young } \\
(\mathrm{N}=24)\end{array}$ & $\begin{array}{c}\text { Elderly } \\
(\mathrm{N}=24)\end{array}$ \\
\hline Unambiguous & Canonical & $1,129.20 \pm 250.17$ & $1,954.57 \pm 392.23$ \\
& Non-canonical & $1,121.38 \pm 209.82$ & $1,926.97 \pm 413.32$ \\
Ambiguous & Canonical & $1,149.26 \pm 275.68$ & $1,966.94 \pm 446.45$ \\
& Non-canonical & $1,154.45 \pm 218.60$ & $2,025.90 \pm 493.82$ \\
\hline
\end{tabular}

Values are presented as mean $\pm S D$.

Table 6. ANOVA results from the reaction time (ms) on the sentence comprehension task

\begin{tabular}{|c|c|c|c|c|}
\hline Distributed source & Sum of squares & Degree of freedom & Mean square & $F$ \\
\hline \multicolumn{5}{|l|}{ Between factor } \\
\hline Group & $33,068,782.72$ & 1 & $33,068,782.72$ & $73.665^{* * *}$ \\
\hline Error & $20,649,810.19$ & 46 & $448,908.917$ & \\
\hline \multicolumn{5}{|l|}{ Within factor } \\
\hline Canonicity & $2,476.696$ & 1 & $2,476.696$ & .139 \\
\hline Canonicity×Group & $3,463.754$ & 1 & $3,463.754$ & .195 \\
\hline Error & $816,799.810$ & 46 & $17,756.518$ & \\
\hline Ambiguity & $81,092.657$ & 1 & $81,092.657$ & $4.123^{*}$ \\
\hline Ambiguity $\times$ Group & $10,148.736$ & 1 & $10,148.736$ & .516 \\
\hline Error & $904,830.674$ & 46 & $19,670.232$ & \\
\hline Canonicity $\times$ Ambiguity & $29,745.561$ & 1 & $29,745.561$ & 2.326 \\
\hline Canonicity $\times$ Ambiguity × Group & $16,230.967$ & 1 & $16,230.967$ & 1.269 \\
\hline Error & $588,314.097$ & 46 & $12,789.437$ & \\
\hline
\end{tabular}

${ }^{*} p<.05,{ }^{* *} p<.01,{ }^{* * *} p<.001$ 


\section{반응시간}

중의성 여부 및 수여동사구문의 어순전형성에 따른 집단 간 문 장판단과제에 대한 반응시간의 차이를 알아보기 위해 집단(청년 층, 노년층), 중의성(중의, 비중의), 전형성(전형, 비전형)을 독립 변 인, 문장판단과제의 반응시간을 종속 변인으로 하는 삼원혼합분 산분석(three-way mixed ANOVA)을 실시하였다. 중의성 및 어순

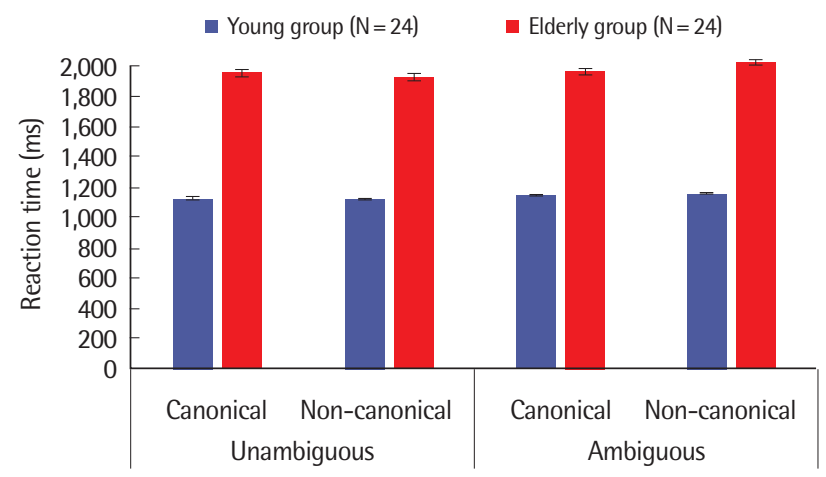

Figure 3. Reaction time on the sentence comprehension task as a function of syntactic ambiguity and word order canonicity for each group (error bar is based on standard error).

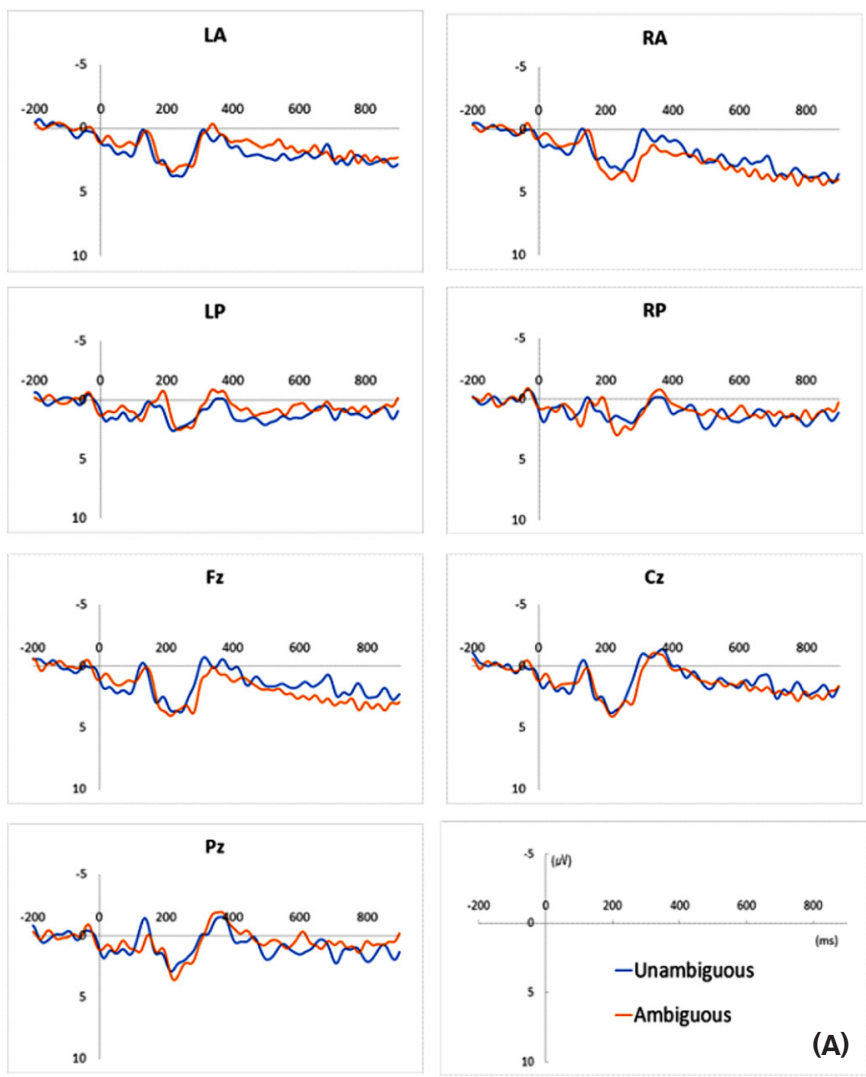

전형성에 따른 집단별 반응시간과 표준편차는 Table 5 과 Figure 3 에 제시하였다.

중의성 여부 및 수여동사구문의 어순전형성에 따른 문장판단과 제의 반응시간에서 중의성과 집단에 대한 주효과가 각각 통계적으 로 유의하였다 $\left(F_{(1,46)}=4.123, p<.05 ; F_{(1,46)}=73.665, p=0.000\right)$. 중 의 조건에서의 평균반응시간이 비중의 조건에서의 평균반응시간 에 비해 유의하게 느리며, 노년층의 평균반응시간이 청년층의 평균 반응시간에 비해 유의하게 느리게 나타났다. 상호작용효과는 나타 나지 않았다. 중의성 여부 및 수여동사구문의 어순전형성에 따른 집단 간 문장판단과제의 반응시간에 대한 분산분석 결과는 Table 6에 제시하였다.

\section{평균진폭(mean amplitude) 크기 분석}

중의성 여부에 따른 집단 및 전형성 같 ERP 평균 파형(grand average wave forms) 결과는 Figures 4-9에 제시하였다. 집단(Younger vs. Elderly) $\times$ 중의성(Unambiguous vs. Ambiguous) $\times$ 어순전형 성(Canonical vs. Non-canonical) $\times$ 반구(Left vs. Right) $\times$ 전후방 (Anterior vs. Posterior)에 대한 오원혼합분산분석(five-way mixed
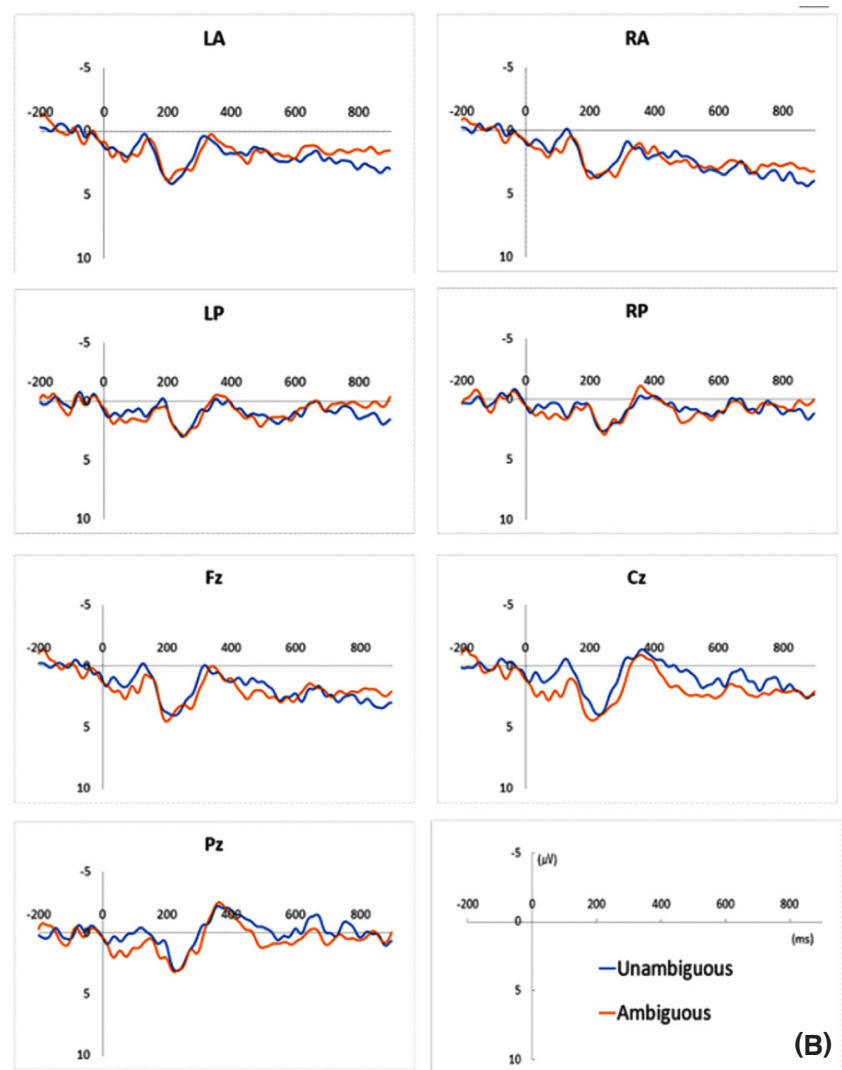

Figure 4. Grand-average waveforms as a function of syntactic ambiguity and word order canonicity in NP2 for young group: (A) canonical and (B) non-canonical. $\mathrm{LA}=$ left anterior; $\mathrm{RA}=$ right anterior; $\mathrm{LP}=$ left posterior; $\mathrm{RP}=$ right posterior. 

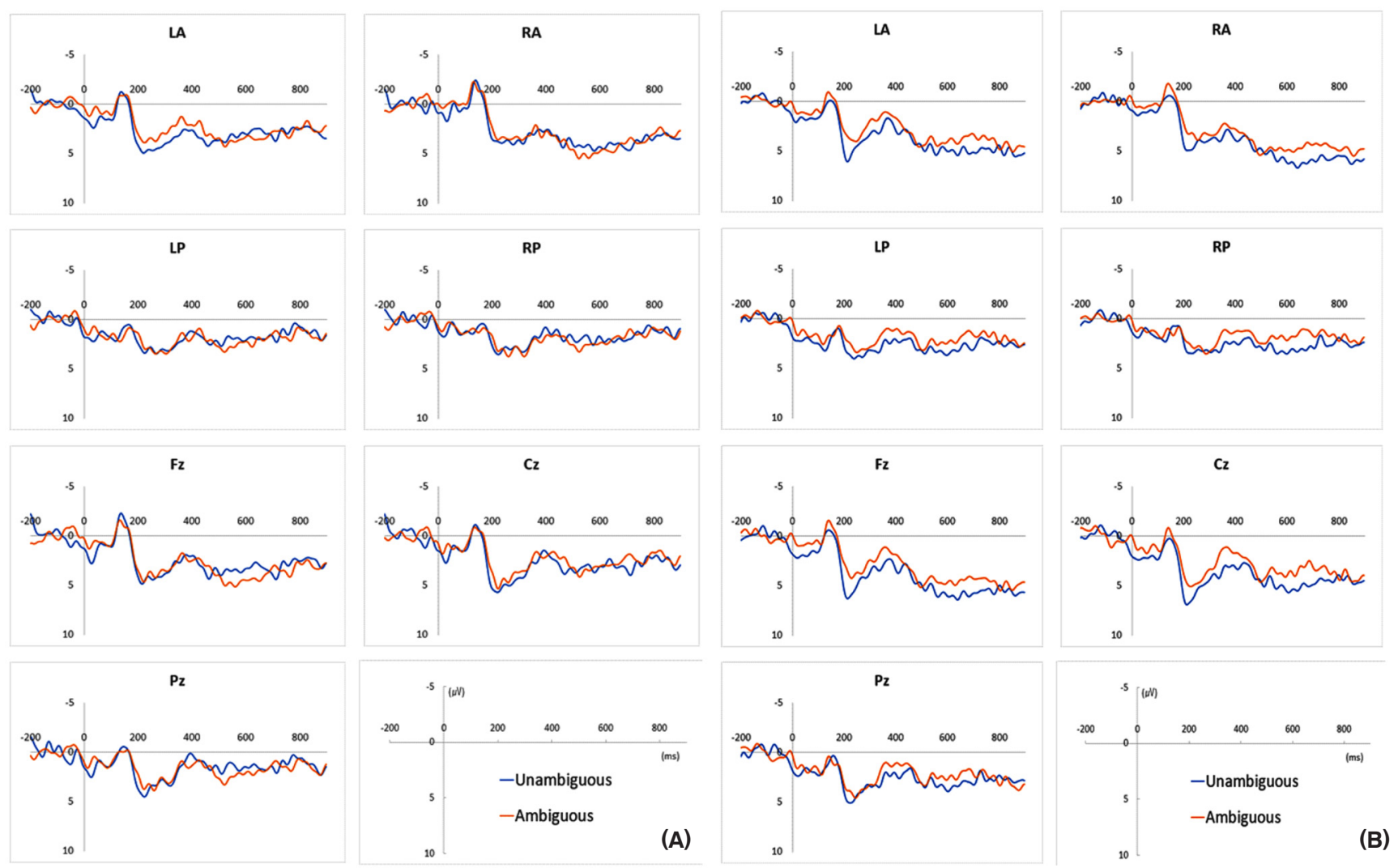

Figure 5. Grand-average waveforms as a function of syntactic ambiguity and word order canonicity in NP2 for elderly group: (A) canonical and (B) non-canonical. $L A=$ left anterior; $R A=$ right anterior; $L P=$ left posterior; $R P=$ right posterior.

ANOVA) 결과는 구간별로 Tables 7-9에 제시하였다. 집단별로 중 의성 $\times$ 어순전형성 $\times$ 반구 $\times$ 전후방에 대한 사원혼합분석(fourway mixed ANOVA) 결과는 Tables 10-12에 제시하였다. 또한, 본 연구는 중의성 및 어순전형성 처리를 살펴보는데 중점을 두고 있 으므로, Tables 7-12에 나타난 중의성 및 어순전형성과 관련한 유의 한 주효과 및 상호작용은 분석 구간별로 나누어 기술하는 부분에 서 보다 상세하게 통계적 효과가 의미하는 바를 기술하였다. 전체 집단분석의 통계적 효과 기술 후에 집단별 분석의 통계적 효과를 기술하였다.

\section{명사구2}

200-500 ms 구간의 평균진폭에서 중의성 및 반구 간 이차상호작 용이 유의하여 $\left(F_{(1,46)}=11.774, p=.001\right)$, 우반구에 비해 좌반구에서 중의성 간 차이가 유의하게 크게 나타났다. 즉, 좌반구에서 중의 조 건의 평균진폭 $(2.061 \mu \mathrm{V})$ 이 비중의 조건의 평균진폭 $(2.410 \mu \mathrm{V})$ 에 비해 부적 방향으로 유의하게 컸다. 또한 중의성, 전형성 및 반구 간 삼차상호작용이 유의미하게 나타났다 $\left(F_{(1,46)}=7.836, p=.007\right)$. 이 에 사후검증으로 전형성별로 중의성 및 반구에 대한 이원혼합분석
을 실시하였다. 그 결과, 비전형 문장에서는 유의미하지 않았지만, 전형 문장에서 유의하게 나타나 $\left(F_{(1,47)}=15.337, p=.000\right)$, 삼차상호 작용이 전형 문장에서의 중의성 및 반구 간 차이에서 기인한 것으 로 확인되었다. 즉, 좌반구에선 중의 조건의 평균진폭 $(2.023 \mu \mathrm{V})$ 이 비중의 조건의 평균진폭 $(2.396 \mu \mathrm{V})$ 보다 상대적으로 부적 방향으로 크며, 우반구에서는 반대로 중의 조건의 평균진폭 $(2.468 \mu \mathrm{V})$ 이 비 중의 조건의 평균진폭 $(2.100 \mu \mathrm{V})$ 보다 정적 방향으로 유의하게 컸 다. 중의성, 반구 및 전후방 간 삼차상호작용도 통계적으로 유의하 게 나타났다 $\left(F_{(1,46)}=6.925, p=.012\right)$. 이에 사후검증으로 전후방별 로 중의성 및 반구에 대한 이원혼합분석을 실시하였다. 그 결과 후 두엽에서는 유의하지 않았지만, 전두엽에서 유의미하게 나타나 $\left(F_{(1,}\right.$ $\left.{ }_{47)}=18.901, p=.000\right)$ 전두엽에선 우반구에 비해 좌반구에서 중의 성 간 차이가 크게 나타난 것에서 삼차상호작용이 기인한 것으로 확인되었다. 즉, 전두엽 내 좌반구에선 중의 조건의 평균진폭 $(2.345$ $\mu \mathrm{V})$ 이 비중의 조건의 평균진폭 $(2.839 \mu \mathrm{V})$ 보다 상대적으로 부적 방 향으로 더 컸다. 200-500 ms 구간의 평균진폭에 대한 집단별 분석 에서는, 노년층에선 중의성 및 어순전형성과 관련한 유의미한 주효 과 및 상호작용효과가 나타나지 않았다. 반면, 청년층에선 중의성 


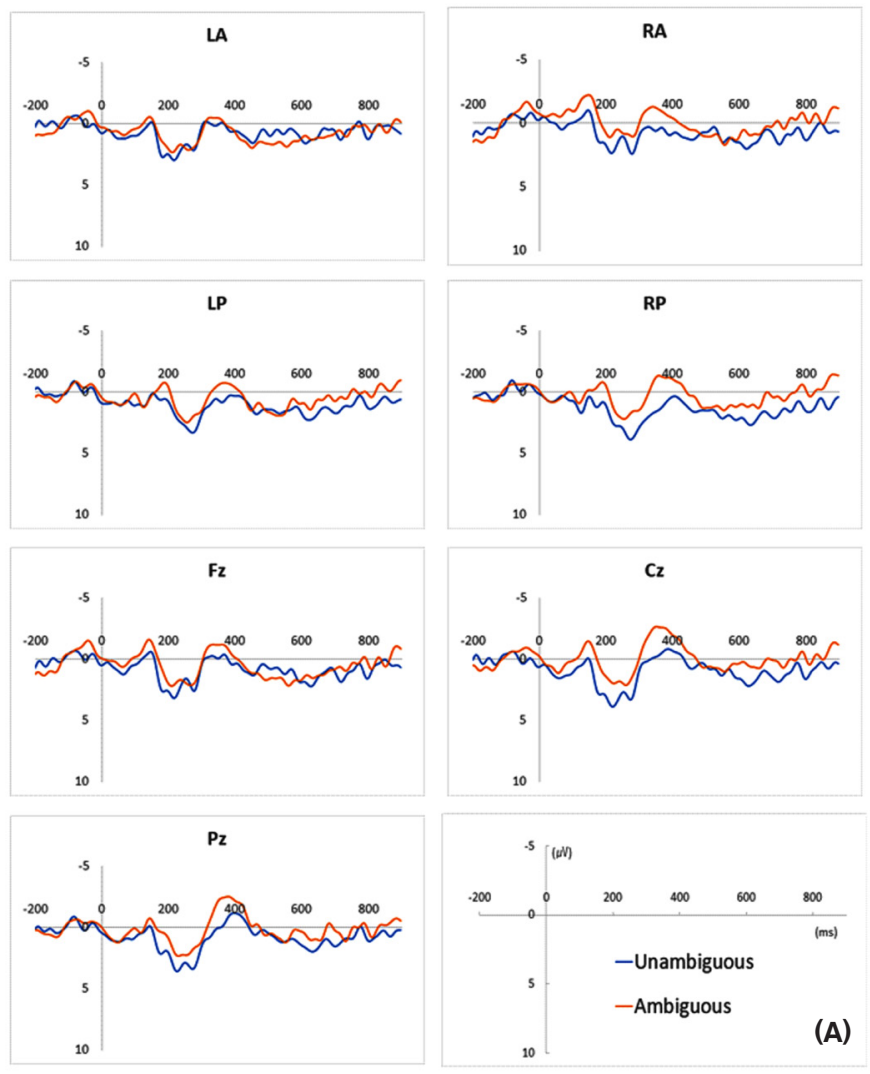

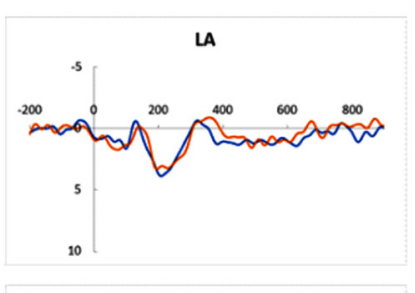
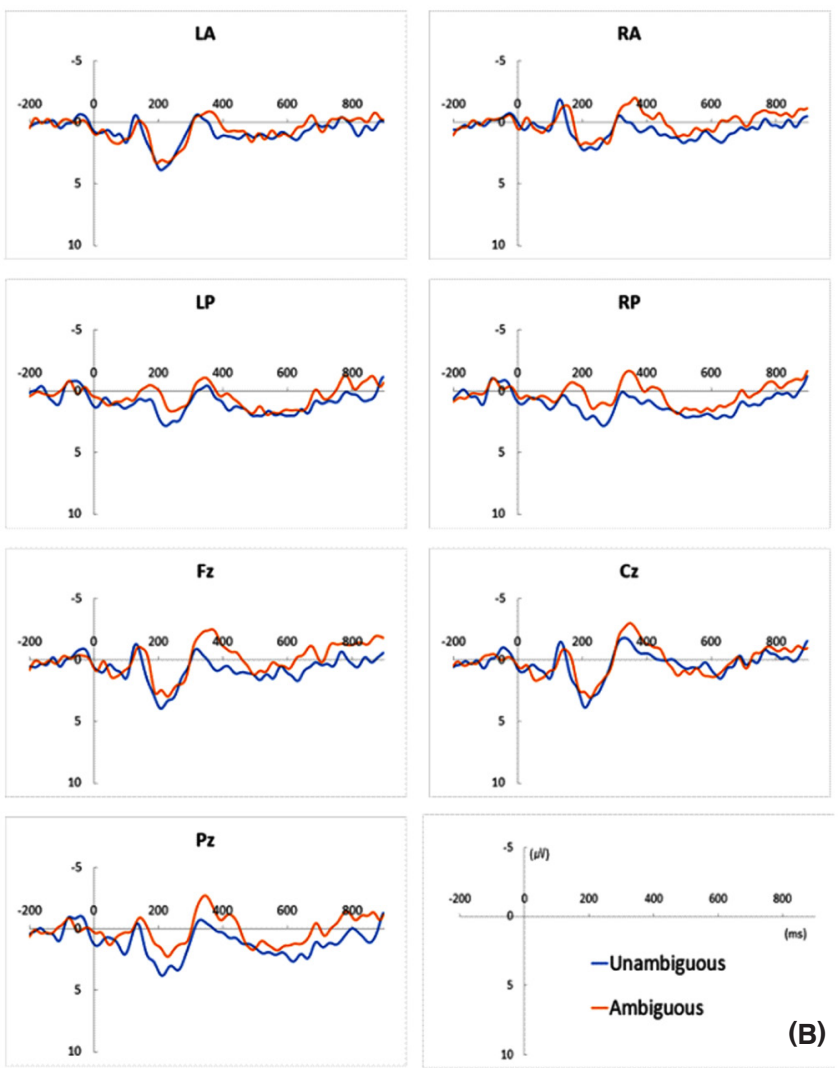

Figure 6. Grand-average waveforms as a function of syntactic ambiguity and word order canonicity in NP3 for young group: (A) canonical and (B) non-canonical. $\mathrm{LA}=$ left anterior; $\mathrm{RA}=$ right anterior; $\mathrm{LP}=$ left posterior; $\mathrm{RP}=$ right posterior.

및 반구 간 이차상호작용이 유의하게 나와 $\left(F_{(1,23)}=7.994, p=.010\right)$, 좌 반구에 비해 우반구에서 중의성 간 차이가 크게 나타났다. 즉, 우반 구에서 중의 조건의 평균진폭 $(1.910 \mu \mathrm{V})$ 이 비중의 조건의 평균진폭 $(1.517 \mu \mathrm{V})$ 에 비해 정적 방향으로 유의하게 컸다. 또한 중의성, 전형 성 및 반구 간 삼차상호작용이 통계적으로 유의하였다 $\left(F_{(1,23)}=\right.$ $8.101, p=.009)$. 이에 사후검증으로 전형성별로 중의성 및 반구에 대한 이원혼합분산분석(two-way repeated ANOVA)을 실시하였다. 비전형 문장에서 유의하지 않았지만, 전형 문장에서 중의성 및 반 구 간 이차상호작용이 유의하게 나왔으며 $\left(F_{(1,23)}=14.431, p=-.001\right)$ 좌반구에 비해 우반구에서 중의성 간 평균진폭 차이가 크게 나타 났다. 즉, 우반구에서 중의 조건의 평균진폭 $(1.972 \mu \mathrm{V})$ 이 비중의 조 건의 평균진폭 $(1.452 \mu \mathrm{V})$ 에 비해 정적 방향으로 유의하게 컸다. 중 의성 반구 및 전후방 간 삼차상호작용도 통계적으로 유의하였다 $\left(F_{(1,23)}=7.199, p=.013\right)$. 이에 사후검증으로 전후방별로 중의성 및 반구 간 이원혼합분석을 실시한 결과, 후두엽에서 유의한 효과가 없었으나, 전두엽에서 유의하게 나타났다 $\left(F_{(1,23)}=12.049, p=.002\right)$. 즉, 좌반구에 비해 우반구에서 전형성 간 차이가 크게 나타났으며,
우반구에서 중의 조건의 평균진폭 $(2.586 \mu \mathrm{V})$ 이 비중의 조건의 평 균진폭 $(1.885 \mu \mathrm{V})$ 에 비해 정적 방향으로 유의하게 컸다.

500-800 ms 구간의 평균진폭에서 중의성, 반구 및 집단 간 삼차 상호작용이 유의하게 나타났다 $\left(F_{(1,46)}=6.197, p=.016\right)$. 이에 사후 검증으로 집단별로 중의성 및 반구에 대한 이원혼합분산분석을 실 시한 결과, 청년층과 노년층 두 집단 모두에서 유의하게 나타났다 $\left(F_{(1,23)}=11.886, p=.002 ; F_{(1,23)}=5.886, p=.024\right)$. 청년층에선 좌반 구에 비해 우반구에서 중의성 간 차이가 크게 나타나, 우반구에서 중의 조건의 평균진폭 $(1.682 \mu \mathrm{V})$ 이 비중의 조건의 평균진폭 $(2.269$ $\mu \mathrm{V}$ )에 비해 상대적으로 부적 방향으로 더 컸다. 노년층에서도 좌반 구에 비해 우반구에서 중의성 간 차이가 크게 나타나, 우반구에서 중의 조건의 평균진폭 $(2.903 \mu \mathrm{V})$ 이 비중의 조건의 평균진폭(3.326 $\mu \mathrm{V}$ )에 비해 상대적으로 부적 방향으로 더 컸다. 즉, 청년층과 노년 층 모두 우반구에서 중의 조건의 평균진폭이 상대적으로 부적 방 향으로 유의하게 컸다. 500-800 ms 구간의 평균진폭에 대한 집단 별 분석에선, 노년층에선 유의미한 주효과 및 상호작용효과가 나타 나지 않았다. 반면, 청년층에선 중의성 및 반구 간 이차상호작용이 


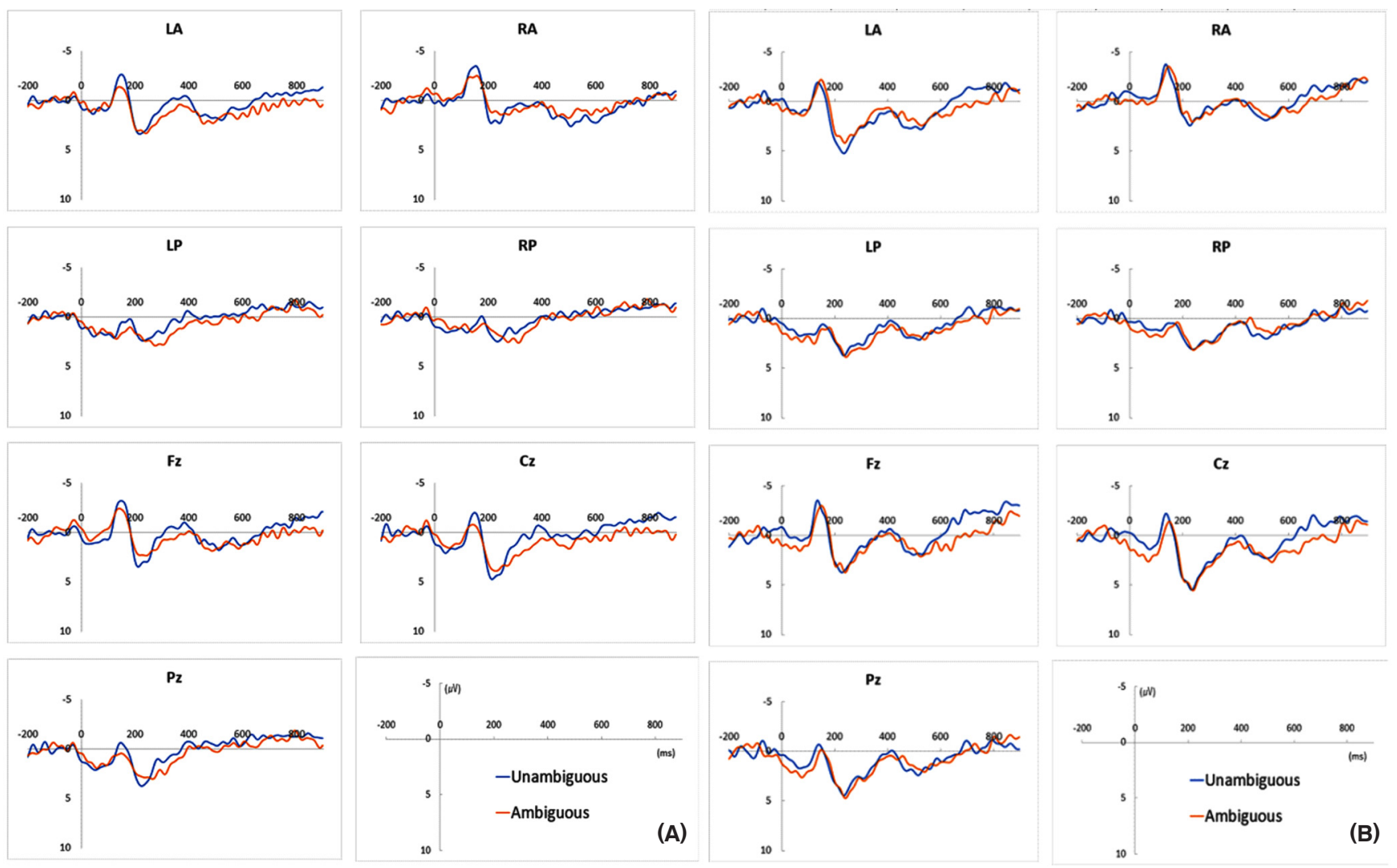

Figure 7. Grand-average waveforms as a function of syntactic ambiguity and word order canonicity in NP3 for elderly group: (A) canonical and (B) non-canonical. $\mathrm{LA}=$ left anterior; $\mathrm{RA}=$ right anterior; $\mathrm{LP}=$ left posterior; $\mathrm{RP}=$ right posterior.

유의하게 나와 $\left(F_{(1,23)}=4.330, p=.049\right)$, 우반구에 비해 좌반구에서 중의성 간 차이가 유의하게 컸다. 좌반구에서 중의 조건의 평균진 폭 $(1.403 \mu \mathrm{V})$ 이 비중의 조건의 평균진폭 $(1.761 \mu \mathrm{V})$ 에 비해 상대적 으로 부적 방향으로 유의하게 컸다.

\section{명사구3}

$100-200 \mathrm{~ms}$ 구간의 평균진폭에서 중의성 및 반구 간 이차상호작 용이 유의하게 나타나 $\left(F_{(1,46)}=4.561, p=.038\right)$, 좌반구에 비해 우반 구에서 중의성 간 평균진폭 차이가 유의하게 큰 것으로 나타났으 며, 우반구에서 중의 조건의 평균진폭 $(-0.156 \mu \mathrm{V})$ 이 비중의 조건의 평균진폭 $(0.199 \mu \mathrm{V})$ 에 비해 부적 방향으로 유의하게 크게 나타났 다. 또한 중의성, 전형성, 전후방 및 집단 간 사차상호작용이 유의미 하게 나타났다 $\left(F_{(1,46)}=5.250, p=.027\right)$. 이에 사후검증으로 전형성 별로 중의성, 전후방 및 집단에 대한 삼원혼합분산분석을 실시한 결과, 전형 문장은 유의미한 효과가 나타나지 않았으나, 비전형 문 장에서 유의하여 $\left(F_{(1,46)}=4.778, p=.034\right)$ 삼차상호작용이 비전형 문장의 후두엽에서 노년층에 비해 청년층이 중의성 간 평균진폭의
차이가 유의하게 큰 데서 기인한 것으로 확인되었다. 즉, 비전형 문 장의 후두엽에서, 청년층은 중의 조건의 평균진폭 $(0.232 \mu \mathrm{V})$ 이 비 중의 조건의 평균진폭 $(1.053 \mu \mathrm{V})$ 보다 부적 방향으로 유의하게 더 크게 나타났다.

200-500 ms 구간의 평균진폭에서 중의성 및 반구 간 이차상호작 용이 유의하게 나타나 $\left(F_{(1,46)}=18.066, p=.000\right)$, 좌반구에 비해 우 반구에서 중의성 간 평균진폭 차이가 유의하게 큰 것으로 나타났으 며, 우반구에서 중의 조건의 평균진폭 $(0.751 \mu \mathrm{V})$ 이 비중의 조건의 평균진폭 $(1.273 \mu \mathrm{V})$ 보다 상대적으로 부적 방향으로 유의하게 크 게 나타났다. 또한 중의성, 전형성, 반구 및 전후방 간 사차상호작용 이 통계적으로 유의미하게 나타났다 $\left(F_{(1,46)}=4.622, p=.037\right)$. 이에 사후검증으로 전후방별로 중의성, 전형성 및 반구에 대한 삼원혼 합분산분석을 실시한 결과, 후두엽에서는 유의하지 않았으나, 전두 엽에서는 유의하게 나타났다 $\left(F_{(1,47)}=6.784, p=.012\right)$. 전두엽에서 삼차상호작용이 유의미하게 나타난 원인을 알아보기 위해, 전형성 별로 중의성 및 반구에 대한 이원혼합분산분석을 실시하였다. 그 결과, 비전형 문장에서는 유의미하지 않았으나, 전형 문장에서 유 


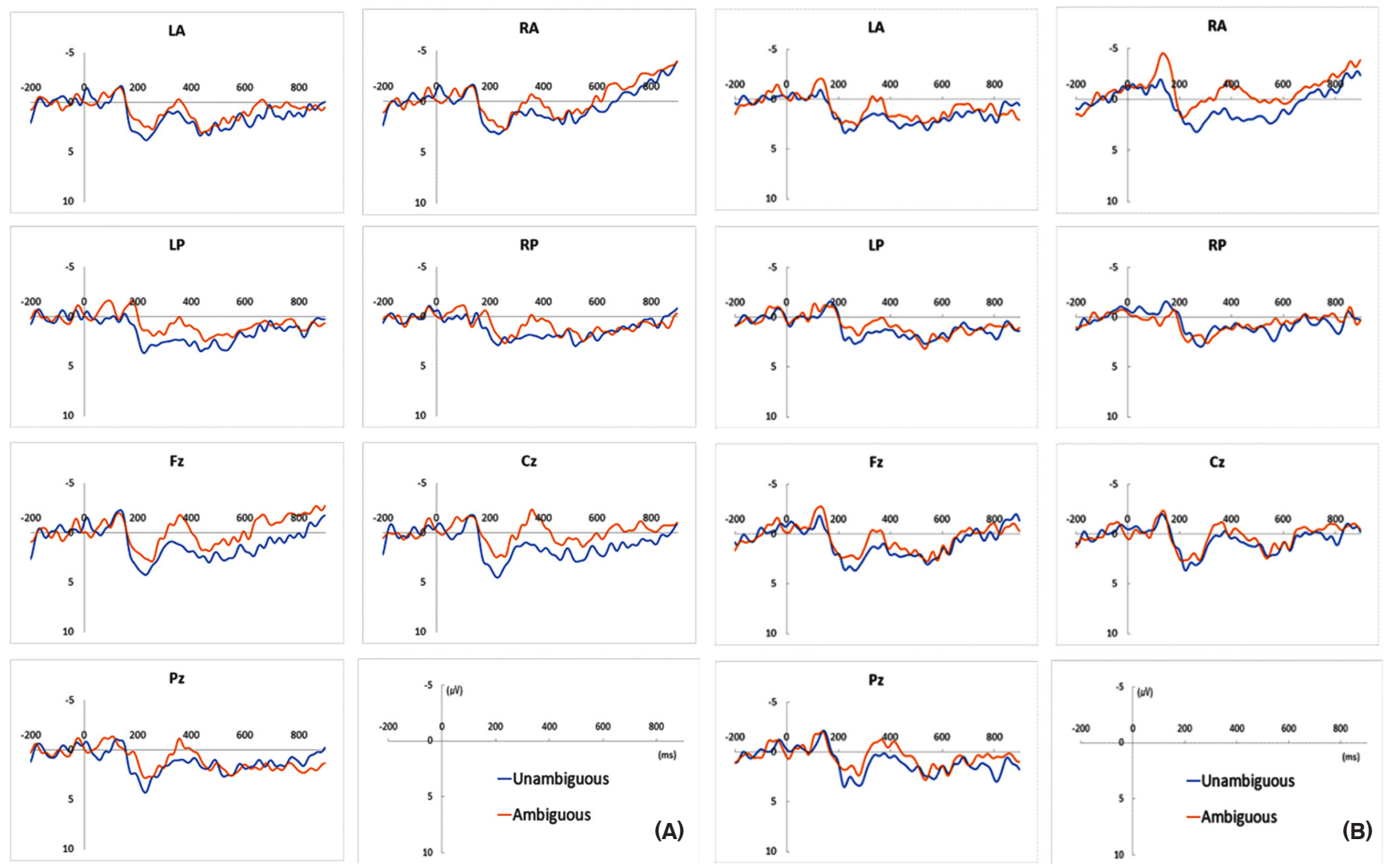

Figure 8. Grand-average waveforms as a function of syntactic ambiguity and word order canonicity in verb for young group: (A) canonical and (B) non-canonical. $\mathrm{LA}=$ left anterior; $\mathrm{RA}=$ right anterior; $\mathrm{LP}=$ left posterior; $\mathrm{RP}=$ right posterior.

의하게 나타났다 $\left(F_{(1,47)}=10.651, p=.002\right)$. 즉, 전두엽 내 전형 문장 은 우반구에서 중의 조건의 평균진폭 $(0.495 \mu \mathrm{V})$ 이 비중의 조건의 평균진폭 $(1.236 \mu \mathrm{V})$ 보다 부적 방향으로 유의하게 크게 나타난 것 으로 확인되었다. 200-500 ms 구간의 평균진폭에 대한 집단별 분 석에선, 청년층에서 중의성 및 반구 간 이차상호작용이 통계적으 로 유의하게 나타나 $\left(F_{(1,23)}=18.673, p=.000\right)$, 좌반구에 비해 우반 구에서 중의성 간 평균진폭의 차이가 유의하게 컸다. 우반구에서 중의 조건의 평균진폭 $(0.457 \mu \mathrm{V})$ 이 비중의 조건의 평균진폭 $(1.468$ $\mu \mathrm{V})$ 에 비해 상대적으로 부적 방향으로 유의하게 크게 나타났다. 노 년층에서 중의성, 전형성, 반구 및 전후방 간 사차상호작용이 유의 미하게 나타났다 $\left(F_{(1,23)}=5.156, p=.033\right)$. 이에 사후검증으로 전후 방별로 중의성, 전형성 및 반구에 대한 삼원혼합분산분석을 실시 한 결과, 후두엽에서는 유의하지 않았으나, 전두엽에서 유의미하게 나타났다 $\left(F_{(1,23)}=5.810, p=.024\right)$. 이에 사후검증으로 반구별과 전 형성별로 각각 이원혼합분산분석을 실시하였으나 유의미한 효과 는 나타나지 않았다. 즉, 노년층에선 중의성과 관련한 통계적으로 유의미한주효과 및 상호작용효과가 나타나지 않았다.
500-800 ms 구간의 평균진폭에서 중의성 및 반구 간 이차상호 작용이 유의하게 나타나 $\left(F_{(1,46)}=14.778, p=.000\right)$, 좌반구에서는 중 의 조건의 평균진폭 $(0.824 \mu \mathrm{V})$ 이 비중의 조건의 평균진폭 $(0.550 \mu \mathrm{V})$ 에 비해 정적 방향으로 유의하게 크게 나타났고, 반대로 우반구에 서는 중의 조건의 평균진폭 $(0.328 \mu \mathrm{V})$ 이 비중의 조건의 평균진폭 $(0.797 \mu \mathrm{V})$ 에 비해 상대적으로 부적 방향으로 유의하게 컸다. 500$800 \mathrm{~ms}$ 구간의 평균진폭에 대한 집단별 분석에서, 청년층에서 중 의성 및 반구 간 이차상호작용이 유의하게 나타나 $\left(F_{(1,23)}=6.127\right.$, $p=0.021)$, 좌반구에 비해 우반구에서 중의성 간 평균진폭의 차이 가 유의하게 컸다. 즉, 우반구에서 중의 조건의 평균진폭 $(0.745 \mu \mathrm{V})$ 이 비중의 조건의 평균진폭 $(1.468 \mu \mathrm{V})$ 에 비해 상대적으로 부적 방 향으로 유의하게 컸다. 노년층에서 중의성 및 반구 간 이차상호작 용이 유의하게 나타나 $\left(F_{(1,23)}=8.694, p=.007\right)$, 우반구에 비해 좌반 구에서 중의성 간 평균진폭의 차이가 크게 나타났다. 즉, 좌반구에서 중의 조건의 평균진폭 $(0.662 \mu \mathrm{V})$ 이 비중의 조건의 평균진폭 $(-0.057$ $\mu \mathrm{V})$ 에 비해 정적 방향으로 유의하게 컸다. 


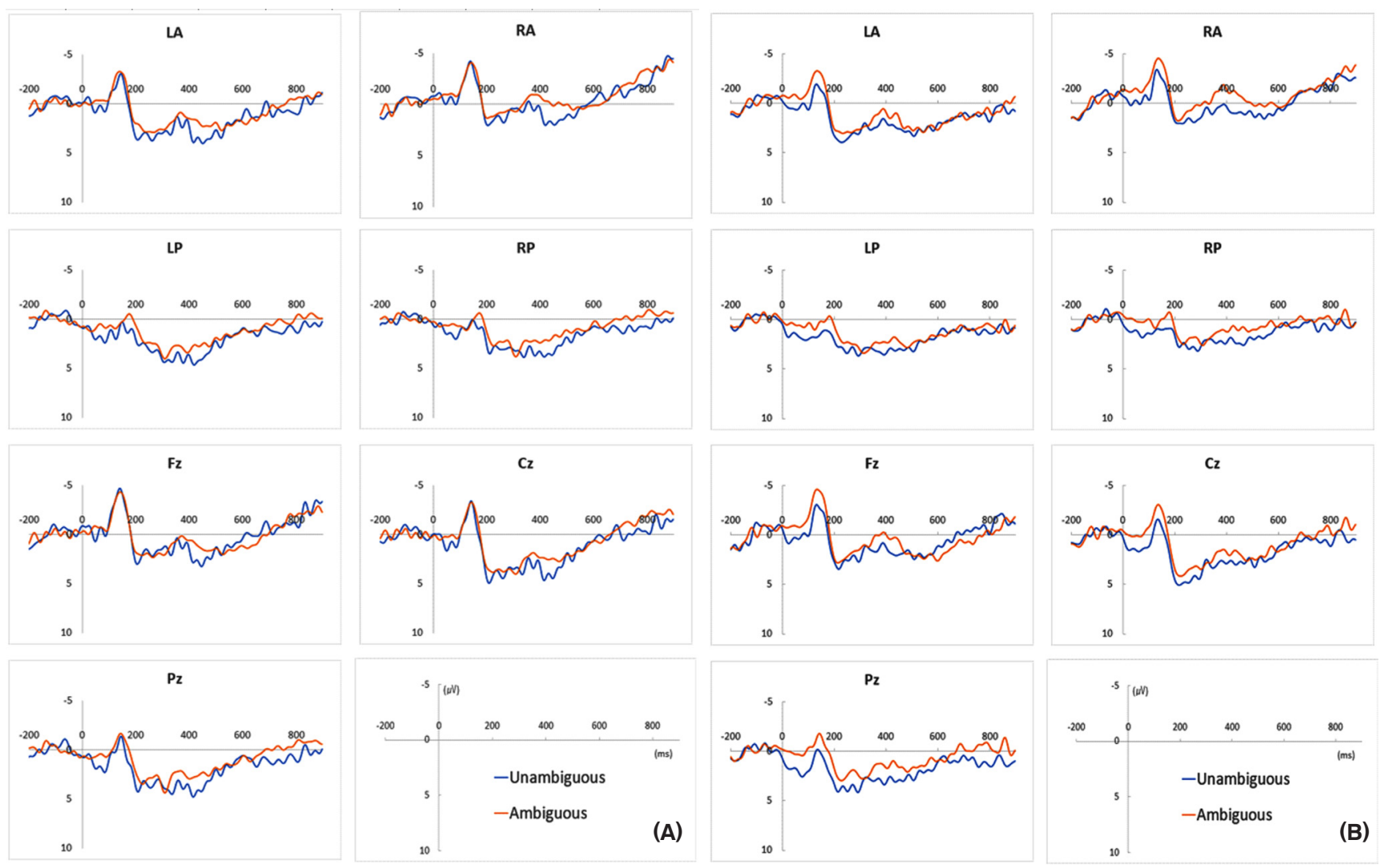

Figure 9. Grand-average waveforms as a function of syntactic ambiguity and word order canonicity in verb for elderly group: (A) canonical and (B) non-canonical. $\mathrm{LA}=$ left anterior; $\mathrm{RA}=$ right anterior; $\mathrm{LP}=$ left posterior; $\mathrm{RP}=$ right posterior.

\section{동사}

$100-200 \mathrm{~ms}$ 구간의 평균진폭에서 중의성에 대한 주효과가 유의 하게 나타나 $\left(F_{(1,46)}=6.313, p=.016\right)$, 중의 조건의 평균진폭 $(-0.600 \mu \mathrm{V})$ 이 비중의 조건의 평균진폭 $(0.053 \mu \mathrm{V})$ 에 비해 부적 방향으로 유의 하게 컸다. 또한, 중의성 및 반구 간 이차상호작용이 유의하여 $\left(F_{(1,46)}=\right.$ $6.217, p=.016)$, 우반구에 비해 좌반구에서 중의성 간 차이가 유의 하게 컸다. 좌반구에서 중의 조건의 평균진폭 $(-0.502 \mu \mathrm{V})$ 이 비중의 조건의 평균진폭 $(0.293 \mu \mathrm{V})$ 에 비해 부적 방향으로 유의하게 크게 나타났다. 200-500 ms 구간의 평균진폭에서 중의성에 대한 주효과 가 유의하게 나타나 $\left(F_{(1,46)}=6.404, p=.015\right)$, 중의 조건의 평균진폭 $(1.438 \mu \mathrm{V})$ 이 비중의 조건의 평균진폭 $(2.267 \mu \mathrm{V})$ 에 비해 상대적으 로 부적 방향으로 유의하게 크게 나타났다. 200-500 ms 구간의 평 균진폭에 대한 집단별 분석에선, 노년층에서 유의한 효과가 나타나 지 않았지만, 청년층에서 중의성에 대한 주효과가 유의하게 나타나 $\left(F_{(1,23)}=4.471, p=.046\right)$ 중의 조건의 평균진폭 $(1.317 \mu \mathrm{V})$ 이 비중의 조건의 평균진폭 $(2.197 \mu \mathrm{V})$ 에 비해 상대적으로 부적 방향으로 유 의하게 크게 나타났다. 500-800 ms 구간의 평균진폭에 대한 집단
별 분석에서, 청년층에서 통계적으로 유의한 효과가 나타나지 않았 지만, 노년층에서 중의성 및 반구 간 이차상호작용이 유의하게 나 타나 $\left(F_{(1,23)}=6.055, p=.022\right)$, 좌반구에 비해 우반구에서 중의성 간 차이가 더 컸다. 즉, 노년층은 우반구에서 중의 조건의 평균진폭 $(-0.261 \mu \mathrm{V})$ 이 비중의 조건의 평균진폭 $(0.011 \mu \mathrm{V})$ 에 비해 부적 방향 으로 유의하게 컸다.

\section{논의 및 결론}

본 연구의 목적은 청년층과 노년층 간 중의성 여부 및 어순전형성 에 따라 수여동사구문 문장처리에서 정반응률, 반응시간 및 ERP 성분의 평균진폭(mean amplitude) 크기에서 유의한 차이가 있는 지 알아보는 것이다. 청년층의 문장판단과제에 대한 정확도는 중의 성 및 어순전형성으로 인해 유의한 영향을 받지 않았다. 모든 문장 유형의 문장판단과제에서 $95 \%$ 이상의 높은 정확도를 보였다. 반응 시간은 비중의 문장에 비해 중의 문장에서 더 오래 걸렸다. ERP 분 석결과에서 전형 문장의 경우, 비중의 조건과 비교하여, 중의 조건 
Table 7. Five-way ANOVA results for mean amplitude in each time window in NP2

\begin{tabular}{|c|c|c|c|}
\hline \multirow{2}{*}{ Effect } & \multicolumn{3}{|c|}{ F-value } \\
\hline & $100-200 \mathrm{~ms}$ & $200-500 \mathrm{~ms}$ & $500-800 \mathrm{~ms}$ \\
\hline G & .148 & 3.381 & 2.701 \\
\hline A & .025 & .227 & .164 \\
\hline$A \times G$ & .773 & .961 & .019 \\
\hline C & 1.511 & .100 & .724 \\
\hline $\mathrm{C} \times \mathrm{G}$ & .720 & .015 & 2.221 \\
\hline L & $6.762^{*}$ & .376 & $6.197^{*}$ \\
\hline$L \times G$ & $5.579^{*}$ & .035 & .286 \\
\hline Ant & .417 & $7.844^{* *}$ & $27.518^{* * *}$ \\
\hline Ant $\times G$ & $11.202^{* *}$ & .014 & 1.144 \\
\hline$A \times C$ & .002 & .258 & 1.235 \\
\hline$A \times C \times G$ & .806 & .639 & .751 \\
\hline$A \times L$ & 1.055 & $11.774^{* *}$ & .869 \\
\hline$A \times L \times G$ & .224 & .352 & $4.988^{*}$ \\
\hline $\mathrm{C} \times \mathrm{L}$ & .309 & .238 & 2.032 \\
\hline$C \times L \times G$ & .478 & 1.473 & .101 \\
\hline$A \times C \times L$ & .016 & $7.836^{* *}$ & .628 \\
\hline$A \times C \times L \times G$ & .108 & .569 & .114 \\
\hline A $\times$ Ant & .963 & .035 & .130 \\
\hline$A \times A n t \times G$ & 1.681 & 1.870 & .055 \\
\hline $\mathrm{C} \times$ Ant & .018 & .353 & 3.275 \\
\hline $\mathrm{C} \times \mathrm{Ant} \times \mathrm{G}$ & .000 & .279 & .578 \\
\hline$A \times C \times A n t$ & .444 & .166 & .326 \\
\hline $\mathrm{A} \times \mathrm{C} \times \mathrm{Ant} \times \mathrm{G}$ & .358 & 1.469 & .369 \\
\hline$L \times$ Ant & $6.858^{*}$ & 1.644 & $6.622^{*}$ \\
\hline$L \times$ Ant $\times G$ & .180 & .213 & .049 \\
\hline$A \times L \times A n t$ & .236 & $6.925^{*}$ & .932 \\
\hline$A \times L \times A n t \times G$ & 1.900 & .702 & .072 \\
\hline$D \times L \times A n t$ & 1.478 & 2.142 & .283 \\
\hline$D \times L \times A n t \times G$ & .300 & .024 & 2.438 \\
\hline$A \times D \times L \times A n t$ & .312 & .892 & .222 \\
\hline$A \times D \times L \times A n t \times G$ & 3.133 & .010 & .634 \\
\hline
\end{tabular}

$\mathrm{NP2}=$ noun phrase $2 ; \mathrm{G}=$ group; $\mathrm{A}=$ ambiguity; $\mathrm{C}=$ canonicity; $\mathrm{L}=$ laterality; $\mathrm{Ant}=$ anteriority.

${ }^{*} p<.05,{ }^{* *} p<.01,{ }^{* * *} p<.001$

일 때 두 번째 명사구 200-500 ms 구간에서 정적 성분(positivity) 을 보여 P300이 확인되었다. 이 결과는 본 연구의 실험문장은 주어 다음에 위치하는 여격어에서 처음 격조사가 생략되기 때문에, 여격 어구가 제시된 후, 예상치 않은 오류(unexpected anomaly)를 감지 하면서 발생한 것으로 해석된다. P300은 문법적 위반은 아니지만 예기치 않은 오류에서 발생한다는 보고와 관련된다(Osterhout, McKinnon, Bersick, \& Corey, 1996). 두 번째 명사구에서 격조사 생략이 처음 나타났기 때문에 오류를 감지하였지만, 한국어는 화 용적으론 격조사를 생략하여 사용하기도 하므로, 격조사 생략을
Table 8. Five-way ANOVA results for mean amplitude in each time window in NP3

\begin{tabular}{|c|c|c|c|}
\hline \multirow{2}{*}{ Effect } & \multicolumn{3}{|c|}{ F-value } \\
\hline & $100-200 \mathrm{~ms}$ & $200-500 \mathrm{~ms}$ & $500-800 \mathrm{~ms}$ \\
\hline G & .906 & .461 & 3.648 \\
\hline A & .564 & .949 & .017 \\
\hline$A \times G$ & 1.708 & 1.808 & 1.794 \\
\hline C & .120 & .090 & .055 \\
\hline $\mathrm{C} \times \mathrm{G}$ & .752 & 1.447 & .272 \\
\hline L & $55.131^{* * *}$ & $11.988^{* *}$ & .392 \\
\hline$L \times G$ & 2.024 & 2.766 & .914 \\
\hline Ant & $14.905^{* * *}$ & .059 & .032 \\
\hline Ant $\times G$ & $17.408^{* * *}$ & .054 & 4.004 \\
\hline$A \times C$ & .034 & .199 & .053 \\
\hline$A \times C \times G$ & .357 & .287 & .342 \\
\hline$A \times L$ & $4.561^{*}$ & $18.066^{* * *}$ & $14.778^{* * *}$ \\
\hline$A \times L \times G$ & 1.465 & 3.392 & .212 \\
\hline$C \times L$ & .784 & $8.436^{* *}$ & 2.202 \\
\hline$C \times L \times G$ & .184 & 3.683 & .835 \\
\hline$A \times C \times L$ & 1.140 & 3.853 & .977 \\
\hline$A \times C \times L \times G$ & .207 & .702 & .859 \\
\hline A $\times$ Ant & .136 & .135 & 1.974 \\
\hline$A \times A n t \times G$ & 1.626 & 3.315 & .129 \\
\hline C $\times$ Ant & 1.368 & .259 & $12.683^{* *}$ \\
\hline$C \times$ Ant $\times G$ & .279 & 1.493 & $4.580^{*}$ \\
\hline$A \times C \times A n t$ & .426 & .011 & .295 \\
\hline$A \times C \times A n t \times G$ & $5.250^{*}$ & .037 & 2.750 \\
\hline L×Ant & $34.578^{* * *}$ & $7.865^{* *}$ & .238 \\
\hline$L \times$ Ant $\times G$ & .152 & .411 & .535 \\
\hline$A \times L \times A n t$ & .018 & .388 & 1.004 \\
\hline$A \times L \times A n t \times G$ & .575 & .376 & .021 \\
\hline$C \times L \times$ Ant & .150 & $7.346^{* *}$ & .631 \\
\hline$C \times L \times A n t \times G$ & $4.225^{*}$ & $13.160^{* *}$ & $6.591^{*}$ \\
\hline$A \times C \times L \times A n t$ & .143 & $4.622^{*}$ & 1.412 \\
\hline$A \times C \times L \times A n t \times G$ & .087 & 1.158 & .045 \\
\hline
\end{tabular}

$\mathrm{NP3}=$ noun phrase $3 ; \mathrm{G}=$ group; $\mathrm{A}=$ ambiguity; $\mathrm{C}=$ canonicity; $\mathrm{L}=$ laterality; $\mathrm{Ant}=$ anteriority.

${ }^{*} p<.05,{ }^{* *} p<.01,{ }^{* * *} p<.001$.

문법적 위반으로 인식하지 않은 것으로 해석된다. 세 번째 명사구 에선 N400과 500-800 ms 구간까지 지속되는 부적 전위가 뚜렷이 확인되었다. 기존 SOV문장 연구들에서 선행하는 명사구에 격조 사를 생략하거나 조작하였다가, 다음에 위치하는 명사구에 격조 사를 제시함으로써, 선행 명사구의 격조사를 다시 예측하여 구문 구조가 재수정되는 과정에서 P600이 발견되었다(Bornkessel, Fiebach, \& Friederici, 2004; Frazier \& Rayner, 1982; Oh et al., 2016).

본 연구의 결과와차이를 보인 것은 통사적 중의성의 조작방식의 차이 때문으로 해석할 수 있다. 본 연구는 선행하는 명사구에 격조 
Table 9. Five-way ANOVA results for mean amplitude in each time window in verb

\begin{tabular}{|c|c|c|c|}
\hline \multirow{2}{*}{ Effect } & \multicolumn{3}{|c|}{ F-value } \\
\hline & $100-200 \mathrm{~ms}$ & $200-500 \mathrm{~ms}$ & $500-800 \mathrm{~ms}$ \\
\hline G & .288 & .138 & .597 \\
\hline$A$ & $6.313^{*}$ & 6.404 & .827 \\
\hline$A \times G$ & .082 & .024 & .427 \\
\hline C & 1.204 & 2.584 & .512 \\
\hline $\mathrm{C} \times \mathrm{G}$ & 1.071 & .045 & .010 \\
\hline L & $6.489^{*}$ & $34.207^{* * *}$ & $26.277^{* * *}$ \\
\hline$L \times G$ & $4.356^{*}$ & $6.528^{*}$ & .966 \\
\hline Ant & $15.375^{* * *}$ & 3.027 & 3.838 \\
\hline Ant $\times G$ & $29.796^{* * *}$ & $5.535^{*}$ & .406 \\
\hline$A \times C$ & .018 & .043 & .482 \\
\hline$A \times C \times G$ & .724 & .337 & .173 \\
\hline$A \times L$ & $6.217^{*}$ & .543 & .891 \\
\hline$A \times L \times G$ & .130 & .660 & 2.171 \\
\hline $\mathrm{C} \times \mathrm{L}$ & $5.302^{*}$ & .173 & 1.633 \\
\hline$C \times L \times G$ & 1.812 & .099 & .034 \\
\hline$A \times C \times L$ & .239 & 1.981 & .043 \\
\hline$A \times C \times L \times G$ & .436 & .020 & .013 \\
\hline$A \times A n t$ & .069 & .041 & .570 \\
\hline$A \times A n t \times G$ & .010 & .346 & 1.438 \\
\hline C $\times$ Ant & 1.003 & $4.936^{*}$ & $4.689^{*}$ \\
\hline $\mathrm{C} \times \mathrm{Ant} \times \mathrm{G}$ & .057 & .084 & .000 \\
\hline$A \times C \times A n t$ & 2.835 & .644 & .336 \\
\hline $\mathrm{A} \times \mathrm{C} \times \mathrm{Ant} \times \mathrm{G}$ & .013 & .097 & .223 \\
\hline$L \times$ Ant & $30.106^{* * *}$ & $16.352^{* * *}$ & $32.739^{* * *}$ \\
\hline$L \times$ Ant $\times G$ & .650 & $8.140^{*}$ & .499 \\
\hline$A \times L \times A n t$ & .456 & 1.977 & .785 \\
\hline$A \times L \times A n t \times G$ & .001 & .036 & .303 \\
\hline$D \times L \times A n t$ & .235 & 1.017 & $6.602^{*}$ \\
\hline$D \times L \times A n t \times G$ & .271 & .461 & 4.027 \\
\hline$A \times D \times L \times A n t$ & .074 & .005 & .203 \\
\hline$A \times D \times L \times A n t \times G$ & 1.512 & 1.460 & 1.128 \\
\hline
\end{tabular}

$\mathrm{G}=$ group; $\mathrm{A}=$ ambiguity; $\mathrm{C}=$ canonicity; $\mathrm{L}=$ laterality; $\mathrm{Ant}=$ anteriority. ${ }^{*} p<.05,{ }^{* *} p<.01,{ }^{* * *} p<.001$.

사가 생략되었으며, 다음에 위치하는 명사구에서도 격조사가 생략 되었다. 그렇기 때문에 제시된 명사구를 모두 읽은 후에 생략된 격 조사들이 기존 연구에서 만큼 명확하게 예측되기는 어렵다고 볼 수 있다. 하지만 본 연구의 실험문장은 여격어는 사람 명사로, 대격 어는 이동할 수 있는 사물 명사를 적용하였기 때문에, 세상지식 (world knowledge)을 활용하여 각 명사구의 의미역을 여격어나 대 격어로 할당(assign)하고, 격조사를 '에게' 또는 '를'로 예측하였다 고 해석할 수 있다. 즉, $\mathrm{N} 400$ 은 통사적 중의성이 높은 문장에서의 의미역 할당과 격조사를 예측하는 과정에서 발생한 것으로 해석된
다. 마지막 동사의 200-500 ms 구간에서 부적 전위가 나타나, 동사 에서도 $\mathrm{N} 400$ 이 확인되었다. 이는 동사구 이전에 처리된 의미역대 로 문장을 처리하다가 동사가 제시되면서, 전체 문장 의미가 명확 해지며 통합이 가능해진 것으로 해석된다. 이 결과는 N400 성분이 문장 내 어휘 처리 후의 통합과정을 반영한다는 통합적 관점을 반 영한다(Kutas \& Hillyard, 1980). 비전형 문장의 경우, 비중의 조건 과 비교하여, 중의 조건일 때 두 번째 명사구 500-800 ms 구간에서 좌반구에서 부적 성분이 확인되었다. 이는 전형 문장의 두 번째 명 사구에서 P300이 발생된 것과는 다른 결과로, 어순전형성의 영향 으로 해석해 볼 수 있다. 기존 비중의 조건의 SOV (주어-목적어-동 사) 문장과 수여동사구문 문장 연구에서 비전형 문장에서 LAN이 발견된 결과와 일치한다(Oh et al., 2016; Rösler et al., 1998). 비중의 문장에 비해, 중의 문장에서 전형 어순의 배열이 이탈된 것을 상대 적으로 더 부담을 갖는 것으로 해석된다. 세 번째 명사구에선 100$200 \mathrm{~ms}$ 구간 좌반구 후두엽의 부적 성분 및 N400과 500-800 ms 구간까지 지속되는 부적 전위가 뚜렷이 확인되었다. 이 결과는 중 의 전형 문장에서와 같은 결과로, 격조사가 모두 생략된 명사구가 차례로 제시되자 각 명사구의 의미역을 세상지식을 적용하여 할당 하고, 격조사를 예측하는 과정에서 발생한 것으로 해석된다. 하지 만 전형 문장에서 보다 이른 구간부터 부적 전위가 발생했다는 차 이가 있다. 어순전형성으로 인한 구문 재구성을 위한 부담이 과중 되어 오랜 기간 동안 처리하고자 이른 구간부터 처리가 일어난 것 으로 해석된다. 마지막 동사의 200-500 ms 구간에서도 부적 전위 가 나타나, 동사에서의 $\mathrm{N} 400$ 이 확인되었다. 이 결과는 의미역과 어 순이 확정된 후, 문장 전체의 의미 및 구문 통합이 일어난 것으로 해석된다. 주어와 목적어의 격조사를 모두 '-ak'으로 마치도록 조 작한 $\mathrm{SOV}$ 중의 문장 연구에서 비전형 문장의 동사에서 부적 전위 가 발생한 결과와 관련된다(Erdocia et al., 2009). 선행연구에서는 세상지식에 따라 의미처리를 하는 과정과 비전형 어순으로 인해 구문 재수정을 하는 과정, 즉 의미처리와 구문처리가 이중으로 발 생하여 부적 전위가 나타났다고 보고하였다.

노년층의 문장판단과제에 대한 정확도는 중의 조건에서 전형 문 장에 비해 비전형 문장에서 유의하게 낮았다. 반응시간은 중의 문 장에서 비중의 문장에 비해 오래 걸렸다. 청년층과 비교하면, 정확 도는 유의하게 낮았고, 반응시간도 유의하게 더 오래 걸렸다. 이 결 과는 중의성과 어순전형성이 노화에 따른 언어능력의 변화와 밀접 하게 관련됨을 시사한다. ERP 분석결과에서 전형 문장의 경우, 비 중의 조건과 비교하여, 중의 조건일 때 두 번째 명사구 200-500 ms 구간에서 더 큰 부적 전위를 보여 $\mathrm{N} 400$ 이 확인되었다. 이 결과는 청년층에서 $\mathrm{P} 300$ 이 나온 결과와 달랐다. 청년층과 달리, 처음 제시 
Table 10. Four-way ANOVA results for mean amplitude in each time window in NP2 for each group

\begin{tabular}{|c|c|c|c|c|c|c|}
\hline \multirow{3}{*}{ Effect } & \multicolumn{6}{|c|}{$F$-value } \\
\hline & \multicolumn{3}{|c|}{ Young group } & \multicolumn{3}{|c|}{ Elderly group } \\
\hline & $100-200 \mathrm{~ms}$ & $200-500 \mathrm{~ms}$ & $500-800 \mathrm{~ms}$ & $100-200 \mathrm{~ms}$ & $200-500 \mathrm{~ms}$ & $500-800 \mathrm{~ms}$ \\
\hline A & .372 & .149 & .066 & .414 & .924 & .101 \\
\hline C & .085 & .025 & .200 & 1.887 & .077 & 2.810 \\
\hline L & .032 & .386 & $6.433^{*}$ & $11.182^{* *}$ & .077 & 1.482 \\
\hline Ant & 3.485 & 3.264 & $7.665^{*}$ & $8.361^{* *}$ & $4.745^{*}$ & $23.126^{* * *}$ \\
\hline$A \times C$ & .388 & .063 & .037 & .418 & .645 & 1.648 \\
\hline$A \times L$ & 1.221 & $7.994^{*}$ & $4.330^{*}$ & .142 & 4.081 & 1.004 \\
\hline $\mathrm{C} \times \mathrm{L}$ & .868 & .231 & 1.282 & .008 & 1.687 & .753 \\
\hline$A \times C \times L$ & .091 & $8.101^{* *}$ & .583 & .024 & 1.713 & .115 \\
\hline AxAnt & .085 & 1.245 & .011 & 1.838 & .839 & .136 \\
\hline $\mathrm{C} \times \mathrm{A}$ & .013 & .682 & .884 & .006 & .002 & 2.398 \\
\hline $\mathrm{A} \times \mathrm{C} \times \mathrm{Ant}$ & .590 & .230 & .467 & .004 & 2.210 & .001 \\
\hline $\mathrm{L} \times$ Ant & 2.518 & 2.370 & 3.636 & 4.437 & .248 & 3.151 \\
\hline$A \times L \times A n t$ & 2.726 & $7.199^{*}$ & 1.553 & .293 & 1.382 & .161 \\
\hline$C \times L \times A n t$ & .180 & .717 & 2.052 & 2.038 & 1.625 & .568 \\
\hline$A \times C \times L \times A n t$ & .728 & .302 & .664 & 2.733 & .666 & .067 \\
\hline
\end{tabular}

$\mathrm{NP2}=$ noun phrase $2 ; \mathrm{A}=$ ambiguity; $\mathrm{C}=$ canonicity; $\mathrm{L}=$ laterality; $\mathrm{Ant}=$ anteriority. ${ }^{*} p<.05,{ }^{* *} p<.01,{ }^{* * *} p<.001$.

Table 11. Four-way ANOVA results for mean amplitude in each time window in NP3 for each group

\begin{tabular}{|c|c|c|c|c|c|c|}
\hline \multirow{3}{*}{ Effect } & \multicolumn{6}{|c|}{ F-value } \\
\hline & \multicolumn{3}{|c|}{ Young group } & \multicolumn{3}{|c|}{ Elderly group } \\
\hline & $100-200 \mathrm{~ms}$ & $200-500 \mathrm{~ms}$ & $500-800 \mathrm{~ms}$ & $100-200 \mathrm{~ms}$ & $200-500 \mathrm{~ms}$ & $500-800 \mathrm{~ms}$ \\
\hline$A$ & 1.337 & 1.635 & .744 & .371 & .193 & 1.328 \\
\hline C & .887 & .512 & .307 & .116 & .938 & .039 \\
\hline L & $17.248^{* * *}$ & 1.513 & .046 & $40.959 * * *$ & $14.123^{* *}$ & 1.510 \\
\hline Ant & .034 & .107 & 1.528 & $55.144^{* * *}$ & .000 & 2.601 \\
\hline$A \times C$ & .244 & .004 & .080 & .114 & .453 & .273 \\
\hline$A \times L$ & 4.280 & $18.673^{* * * *}$ & $6.127^{*}$ & .618 & 2.883 & $8.694^{* *}$ \\
\hline$C \times L$ & .085 & .339 & .133 & 1.111 & $20.491^{* * *}$ & 3.704 \\
\hline$A \times C \times L$ & .207 & .844 & .003 & 1.062 & 3.136 & 1.409 \\
\hline AxAnt & .267 & 2.052 & 1.475 & 2.945 & 1.267 & .579 \\
\hline$C \times A$ & 1.872 & .232 & 1.008 & .167 & 1.659 & $16.288^{* *}$ \\
\hline $\mathrm{A} \times \mathrm{C} \times \mathrm{Ant}$ & 3.163 & .041 & .916 & 2.132 & .004 & 1.834 \\
\hline$L \times$ Ant & $18.855^{* * *}$ & 3.472 & .829 & $15.742^{* *}$ & $4.476^{*}$ & .027 \\
\hline$A \times L \times A n t$ & .191 & .000 & .558 & .406 & 1.124 & .447 \\
\hline $\mathrm{C} \times \mathrm{L} \times$ Ant & 1.728 & .381 & 1.235 & 2.497 & $22.435^{* * *}$ & $7.762^{*}$ \\
\hline$A \times C \times L \times A n t$ & .287 & .582 & .492 & .003 & $5.156^{*}$ & .949 \\
\hline
\end{tabular}

NP3 = noun phrase $3 ; A=$ Ambiguity, $C=$ Canonicity, $L=$ Laterality, Ant= Anteriority. ${ }^{*} p<.05,{ }^{* *} p<.01,{ }^{* * *} p<.001$.

된 격조사 생략 명사구를 의미적 오류로 인식했을 가능성이 있다. $\mathrm{N} 400$ 은 의미적으로 오류를 가진 문장에서 주로 관찰되는 성분으 로 알려져 있다(Kutas \& Federmeier, 2011). 세 번째 명사구 500$800 \mathrm{~ms}$ 구간에서 정적 전위를 보여 P600이 뚜렷이 관찰되었다. 이
는 청년층에서 $\mathrm{N} 400$ 이 나온 결과와 다르지만, 대부분의 SOV 중의 문장에서 P600이 나타난 결과와 일치한다(Bornkessel et al., 2004; Frazier \& Rayner, 1982; Oh et al., 2016). SOV 중의 문장처리 연구 들은 주로 격조사 생략 명사구 다음에 위치한 명사구에서 의미역 
Table 12. Four-way ANOVA results for mean amplitude in each time window in verb for each group

\begin{tabular}{|c|c|c|c|c|c|c|}
\hline \multirow{3}{*}{ Effect } & \multicolumn{6}{|c|}{ F-value } \\
\hline & \multicolumn{3}{|c|}{ Young group } & \multicolumn{3}{|c|}{ Elderly group } \\
\hline & $100-200 \mathrm{~ms}$ & $200-500 \mathrm{~ms}$ & $500-800 \mathrm{~ms}$ & $100-200 \mathrm{~ms}$ & $200-500 \mathrm{~ms}$ & $500-800 \mathrm{~ms}$ \\
\hline A & 2.695 & $4.471^{*}$ & 1.248 & 3.625 & 2.364 & .032 \\
\hline C & 1.444 & .850 & .231 & .005 & 1.937 & .336 \\
\hline$L$ & .092 & $4.306^{*}$ & $6.442^{*}$ & 12.626 & $47.700^{* * *}$ & $27.947^{* * *}$ \\
\hline Ant & 1.210 & .221 & 3.074 & $43.003^{* * *}$ & $7.271^{*}$ & .966 \\
\hline$A \times C$ & .211 & .077 & .046 & .617 & .285 & .533 \\
\hline$A \times L$ & 3.765 & .002 & .092 & 2.477 & 2.400 & $6.055^{*}$ \\
\hline$C \times L$ & $4.894^{*}$ & .005 & .462 & .715 & .269 & 1.514 \\
\hline$A \times C \times L$ & .017 & .689 & .003 & .572 & 1.430 & .132 \\
\hline$A \times A n t$ & .054 & .301 & 1.894 & .017 & .077 & .099 \\
\hline$C \times A$ & .677 & 2.383 & 3.734 & .336 & 2.758 & 1.704 \\
\hline$A \times C \times A n t$ & 1.020 & .112 & .005 & 2.039 & .674 & .608 \\
\hline L×Ant & $16.063^{* *}$ & 1.199 & $11.833^{* *}$ & $15.023^{* *}$ & $16.882^{* * *}$ & $22.047^{* * *}$ \\
\hline$A \times L \times A n t$ & .149 & .892 & .699 & .583 & 1.291 & .107 \\
\hline$C \times L \times$ Ant & .361 & .037 & $9.585^{* *}$ & .001 & 2.682 & .174 \\
\hline$A \times C \times L \times A n t$ & .898 & .550 & .679 & .617 & 1.251 & .594 \\
\hline
\end{tabular}

$\mathrm{A}=$ Ambiguity, $\mathrm{C}=$ Canonicity, $\mathrm{L}=$ Laterality, Ant $=$ Anteriority. ${ }^{*} p<.05,{ }^{* *} p<.01,{ }^{* * *} p<.001$.

이 확정됨에 따라 통사적 중의성이 해결되는 과정에서 P600이 발 생하였다고 보고하였다. 반면, 본 연구에선 두 번째로 격조사 생략 이 제시되는 위치로, 의미역이 정해져서 통사적 중의성이 해결되었 다고 보기 어렵다. 오히려 여격어와 대격어의 격조사 생략이 모두 제시된 후에 P600이 발생하였으므로, 모든 격조사 생략을 통사적 오류로 인식했거나 격조사를 예측하여 구문을 재구조화 하려고 했을 가능성이 있다. P600은 구문구조나 격(case) 위반 등 통사적 오류를 가진 문장에서 주로 관찰되는 성분으로 알려져 있다(Coulson, King, \& Kutas, 1998). 동사의 500-800 ms 구간에서 부적 성분 을 보였다. 청년층에서 뚜렷한 N400을 보인 것과 대조된다. 앞서 의 미 및 통사적 오류를 인식하였지만 의미역 할당이 충분히 진행되 지 않아, 동사에서 의미 및 구문 통합 과정이 상대적으로 비활성화 되는 양상으로 해석된다. 비전형 문장의 경우, 비중의 조건과 비교 하여, 중의 조건일 때 두 번째 명사구 500-800 ms 구간 우반구에서 부적 성분이 관찰되었으며, 세 번째 명사구에서 P600, 동사 100-200 $\mathrm{ms}$ 구간 좌반구에서 부적 성분을 보여, 전형 문장과 유사한 양상 의 문장처리를 하였다. 전형 문장에 비해, 부적 전위가 두 번째 명 사구에서 늦게 나타나고, 동사에선 이른 구간에 짧게 나타났다는 차이가 있다. 이 결과는 어순전형성을 반영하는 것으로 보인다. 두 번째 명사구에서 격조사 생략과 비전형 어순을 동시에 인식하는 과정에서 지연이 일어난 것으로 볼 수 있다. 동사에서는 전체 문장 의 의미 및 구문 통합을 시도한 것으로 보이나, 이른 구간에서만 출
현하였으므로 충분히 처리되지 않았을 것으로 예상할 수 있다.

기존 SOV 중의 문장 연구결과는 공통적으로 중의 문장에서 $\mathrm{P} 600$ 이 관찰되었다. 격조사가 생략되거나 조작된 명사구 다음에 격조사가 있는 명사구가 제시되면, 제시된 격조사를 통해 생략된 격조사를 예측하여 명사구의 의미역을 할당하고 구문구조를 재수 정하는 과정 중에 발생하는 성분으로 해석되어왔다(Erdocia et al., 2009; Frisch, Schlesewsky, Saddy, \& Alpermann, 2002; Oh et al., 2016). 본 연구의 수여동사구문 중의 문장처리에서 청년층은 N400 을 나타냈고, 노년층은 $\mathrm{P} 600$ 을 나타냈다. 청년층의 중의 문장판단 과제 정확도가 $95 \%$ 이상으로 매우 높았으므로, 청년층에서 발생된 $\mathrm{N} 400$ 은 여격어와 대격어의 격조사가 모두 생략되어 제시되면, 격 조사를 바로 예측하는 데 한계가 있지만 주로 여격어는 사람이고, 대격어는 물건이란 의미와 관련된 세상지식을 활용하여 격조사를 예측하고 의미역을 할당하는 처리과정을 의미한다고 볼 수 있다. 반면, 노년층은 여격어와 대격어의 모든 격조사 생략을 통사적 오 류로 인식하여 $\mathrm{P} 600$ 이 발생된 것으로 해석된다. SOV 중의 문장의 $\mathrm{P} 600$ 과는 다른 특성으로, 대부분의 중의 문장에서 P600이 중의성 해결 시에 발생한 결과와 다르다. 또한, 기존 SOV 중의 문장에선 전 형 어순과 비전형 어순 모두에서 P600을 보여, 같은 ERP 성분이 관 찰되었다(Frisch et al., 2002). 수여동사구문 중의 문장처리에서 청 년층은 두 번째 명사구에서 전형 어순일 때 P300, 비전형 어순일 때 부적 성분으로 각각 다르게 나타냈다. 반면 노년층은 어순전형성 
과 관계없이 부적 성분(명사구2), $\mathrm{P} 600$ (명사구3), 부적 성분(동사) 을 나타냈으며 비전형 어순에서 문장처리가 늦게 시작하고 빨리 마 쳤다. 청년층의 어순전형성 간 중의 문장판단과제 정확도가 모두 95\%이상으로 매우 높았으므로, SOV 중의 문장에 비해 수여동사 구문 문장의 ERP 처리양상에서 어순전형성이 더 구별되게 나타나 는 것으로 해석된다. 반면, 노년층은 중의 비전형 문장에서 중의성 및 어순전형성으로 인한 부담이 증가되었지만, 통합처리는 더 짧은 시간에 처리되어 비전형 어순에서 정확도가 유의하게 낮아진 것으 로 확인된다. 요컨대, 여격어와 대격어의 격조사가 모두 생략된 수 여동사구문 문장처리 시 청년층과 노년층의 통사적 중의성 여부와 어순전형성에 대한 처리양상이 유의하게 달랐다. 노년층에서 나타 난 ERP 양상은 노화로 인해 문장이해능력의 변화가 일어난 특징 으로 볼 수 있다. 기존 노년층 대상 ERP 연구에서 노화로 인해 평균 진폭이 작아지거나 지연됨을 보고한 반면에 본 연구에서는 N400 및 $\mathrm{P} 600$ 인 다른 $\mathrm{ERP}$ 성분이 발견된 점이 특징적이다. $\mathrm{SOV}$ 문장에 비해 어구(phrase)가 증가된 점, 수여동사구문 문장의 특수성, 격 조사생략 개수의 증가로 통사적 중의성이 높아진 점이 문장처리양 상이 구별되어 나타나는 데 영향을 미쳤을 것으로 생각된다. 노년 층이 통사적으로 복잡한 문장을 청년층과 다르게 인식하여 처리 하는 이유는 노화로 인한 인지변화와 연관 지어 해석할 수 있겠다. 노화는 인지변화에 영향을 주는 것으로 알려져 있으며, 인지영역 의 하나인 작업기억 용량의 감소와도 관련 있다고 보고되고 있다 (Gazzaley, Cooney, Rissman, \& D'esposito, 2005; Lee, Kim, Lee, Chung, \& Park, 2012; Park, 2004). 또한 언어적 작업기억 폭이 높은 집단과 낮은 집단 간 중의성 및 전형성 여부에 따른 SOV 문장처리 양상의 특징이 전위방향이 서로 다른 ERP 성분으로 나타난 기존 연구결과가 있다(Bornkessel et al., 2004). 본 연구에선 언어적 작업 기억 폭에 대한 검증은 하지 않았기 때문에 작업기억 용량을 기반 으로 한 해석에는 주의를 요하나, 노화로 인한 언어적 작업기억 용 량의 변화가 통사적으로 복잡한 문장처리양상에 영향을 미쳐서 $\mathrm{N} 400, \mathrm{P} 600$ 과 같이 서로 다른 ERP 성분을 발생시켰을 가능성을 생각해볼수 있다.

본 연구의 제한점 및 후속연구를 위한 제언은 다음과 같다. 첫째, 본 연구의 대상자와 관련하여, 청년층 평균연령은 28.33 세, 범위는 20-37세로 청년층을 대표할 만한 표본인데 반해, 노년층은 연령 범 위가 60-74세이고 평균연령이 63.92세로 60대 초반의 노인군으로 구성되어 있어서, 본 연구결과를 고령의 노년층까지 일반화해서 해 석하기엔 한계가 있을 수 있다. 따라서 추후 고령층을 포함한 많은 수의 노인들을 대상으로 한 연구가 필요하겠으며, 더 나아가, 노년 층 연구를 기반으로 다양한 언어장애군을 대상으로 한 비교연구가
필요하겠다. 정상, 경도인지장애군, 치매 등 퇴행성 질환이 진행되 는 시점에 따른 특징을 파악하는 것도 향후 연구에서 이뤄질 수 있 겠다. 둘째, 본 연구에서 사용된 자극문장과 관련하여, 수여동사의 범위는 넓은데, 본 연구에서는 그 중 단일동사의 형태로 수여동사 구문을 형성하는 동사(원형적 수여동사, 확장적 수여동사)를 선정 하였으며, 주어와 여격어를 사람명사로 한정하였다. 이에 모든 수여 동사구문에서 동일한 연구결과가 나온다고 보기엔 성급한 결론일 수 있다. 추후 수여동사구문 문장을 구성하는 명사구들의 조건을 달리한 연구가 진행될 수 있겠으며, 더 나아가 보다 다양한 문장유 형을 대상으로 한 연구가 진행될 필요가 있다. 마지막으로, 뇌 영역 과 관련된 연구결과에 대한 해석은 논의에서 자제하였다. 이는 ERP 특성상, 시간해상도가 높은 반면 공간해상도는 낮으므로 특정 뇌 파가 관찰된 뇌 영역을 그 뇌파의 발생 원인으로 해석하는 데 제한 되기 때문이다(Luck, 2005). 뇌영역과 관련된 효과는 추후 Source Analysis 분석방법을 활용한 연구에서 깊이 있게 논의될 수 있기를 기대한다. 이상의 연구들이 지속적으로 진행된다면, 한국어 사용 자의 보다 심층적인 언어손상 특징 파악과 그를 위한 치료법이 심 도 있게 연구 및 개발될 수 있을 것으로 예상된다.

본 연구는 한국어 사용자 청년층과 노년층 대상으로 통사적 중 의성 여부 및 어순전형성을 조절하였을 때 수여동사구문 문장처리 과정의 뇌파 분석결과와 오프라인 행동결과가 어떠한 차이를 보이 는지 살펴본 연구이다. 기존의 SOV 문장처리 과정에 대한 연구를 확장시켜, 한국어의 수여동사구문 문장처리의 과정을 통사적 중의 성과 전형성을 모두 조절하여 살펴보았다. 정상적인 노화로 인한 변화의 특성과 범위를 설정해가는 데 기초연구 자료로서 기능할 수 있다는 측면에서 본 논문의 임상적 의의가 있다.

\section{REFERENCES}

Bahlmann, J., Rodriguez-Fornells, A., Rotte, M., \& Münte, T. F. (2007). An fMRI study of canonical and noncanonical word order in German. Human Brain Mapping, 28, 940-949.

Bayles, K. A., Tomoeda, C. K., \& Trosset, M. W. (1990). Naming and categorical knowledge in Alzheimer's disease: the process of semantic memory deterioration. Brain and Language, 39, 498-510.

Bornkessel, I. D., Fiebach, C. J., \& Friederici, A. D. (2004). On the cost of syntactic ambiguity in human language comprehension: an individual differences approach. Cognitive Brain Research, 21, 11-21.

Caplan, D., DeDe, G., Waters, G., Michaud, J., \& Tripodis, Y. (2011). Effects of age, speed of processing, and working memory on comprehension of 
sentences with relative clauses. Psychology and Aging, 26, 439-450.

Cheon, J. H. (2016). Animacy effects of the subject-noun phrase on age-related differences in sentence processing: evidence from ERP (Master's thesis). Ewha Womans University, Seoul, Korea.

Chertkow, H., \& Bub, D. (1990). Semantic memory loss in dementia of Alzheimer's type: what do various measures measure? Brain, 113, 397-417.

Christensen, K. J., Multhaup, K. S., Nordstrom, S. K., \& Voss, K. A. (1991). A new cognitive battery for dementia: relative severity of deficits in Alzheimer's disease. Developmental Neuropsychology, 7, 435-449.

Coulson, S., King, J. W., \& Kutas, M. (1998). Expect the unexpected: eventrelated brain response to morphosyntactic violations. Language and Cognitive Processes, 13, 21-58.

Erdocia, K., Laka, I., Mestres-Missé, A., \& Rodriguez-Fornells, A. (2009). Syntactic complexity and ambiguity resolution in a free word order language: behavioral and electrophysiological evidences from Basque. Brain and Language, 109, 1-17.

Ferreira, F., \& Cokal, D. (2015). Sentence processing. In G. Hickok \& S. L. Small (Eds.), Neurobiology of language (pp. 265-274). New York, NY: Academic Press.

Frazier, L., \& Rayner, K. (1982). Making and correcting errors during sentence comprehension: eye movements in the analysis of structurally ambiguous sentences. Cognitive Psychology, 14, 178-210.

Friederici, A. D. (2011). The brain basis of language processing: from structure to function. Physiological Reviews, 91, 1357-1392.

Frisch, S., Schlesewsky, M., Saddy, D., \& Alpermann, A. (2002). The P600 as an indicator of syntactic ambiguity. Cognition, 85, B83-B92.

Gazzaley, A., Cooney, J. W., Rissman, J., \& D’esposito, M. (2005). Top-down suppression deficit underlies working memory impairment in normal aging. Nature Neuroscience, 8, 1298-1300.

Grossman, M., Cooke, A., DeVita, C., Alsop, D., Detre, J., Chen, W., \& Gee, J. (2002). Age-related changes in working memory during sentence comprehension: an fMRI study. Neuroimage, 15, 302-317.

Hagiwara, H., Soshi, T., Ishihara, M., \& Imanaka, K. (2007). A topographical study on the event-related potential correlates of scrambled word order in Japanese complex sentences. Journal of Cognitive Neuroscience, 19, 175-193.

Hwang, B. H. (2003). A study on ditransitive construction in Korean (Master's thesis). Kyung Hee University, Seoul, Korea.

Im, H. P. (2007). Language typological approach to word order and basic word order of Korean. Humanities Journal, 22, 53-120.

Jasper, H. H. (1958). The ten-twenty electrode system of the International
Federation. Electroencephalography and Clinical Neurophysiology, 10, 370375.

Jo, E. H., \& Sung, J. E. (2018). Age-related differences in ERP components associated with processing homonyms depending on the context type of adnominal and verb phrases. Communication Sciences \& Disorders, 23, 360377.

Kaan, E. (2007). Event-related potentials and language processing: a brief overview. Language and Linguistics Compass, 1, 571-591.

Kaan, E., \& Swaab, T. Y. (2003). Repair, revision, and complexity in syntactic analysis: an electrophysiological differentiation. Journal of Cognitive Neuroscience, 15 , 98-110.

Kang, Y., \& Na, D. L. (2003). Seoul Neuropsychological Screening Battery. Seoul: Human Brain Research \& Consulting Co.

Kang, Y., Na, D. L., \& Hahn, S. (1997). A validity study on the Korean MiniMental State Examination (K-MMSE) in dementia patients. Journal of the Korean Neurological Association, 15, 300-308.

Kemmer, L., Coulson, S., De Ochoa, E., \& Kutas, M. (2004). Syntactic processing with aging: an event-related potential study. Psychophysiology, 41, 372-384.

Kim, D. S. (2002). About basic word order in Korean sentence. Hanshin Journal of Humanities, 3, 5-27.

Kim, J., Sung, J. E., Lee, S. E., \& Sim, H. S. (2018). ERP components associated with locality dependency of time references between young and elderly adults. Communication Sciences \& Disorders, 23, 129-145.

Kutas, M., \& Federmeier, K. D. (2011). Thirty years and counting: finding meaning in the N400 component of the event-related brain potential (ERP). Annual Review of Psychology, 62, 621-647.

Kutas, M., \& Hillyard, S. A. (1980). Reading senseless sentences: brain potentials reflect semantic incongruity. Science, 207, 203-205.

Lee, H. W., Kim, S. K., Lee, K. E., Chung, E. J., \& Park, J. Y. (2012). The agerelated changes in cognitive function. Korean Journal of Cognitive and Biological Psychology, 24, 127-148.

Lee, M. S., \& Kim, H. H. (2011). Characteristics of expressive language in normal aging, mild cognitive impairment, and Alzheimer's disease. Dementia and Neurocognitive Disorders, 10, 69-79.

Luck, S. J. (2005). An introduction to the event-related potential technique. Cambridge, MA: MIT Press.

Martin, S. E. (1992). A reference grammar of Korean: a complete guide to the grammar and history of the Korean language. Tokyo: Tuttle Publishing.

Matzke, M., Mai, H., Nager, W., Rüsseler, J., \& Münte, T. (2002). The costs of 
freedom: an ERP-study of non-canonical sentences. Clinical Neurophysiology, 113, 844-852.

Ministry of Health and Welfare. (2012). The 2nd National Dementia Plan. Seoul: Author.

Nam, Y. J. (2014). Semantic integration in sentence comprehension: An ERP study in Korean (Doctoral dissertation). Konkuk University, Seoul, Korea.

National Institute of Korean Language. (2005). Frequency in use of Modern Korean. Seoul: Author.

Oh, S. J., \& Sung, J. E. (2017). Age-related differences in ERP components during Korean honorific sentence processing depending on listener's social status and predicate agreement. Communication Sciences \& Disorders, 22, 101-116.

Oh, S. J., Sung, J. E., \& Sim, H. S. (2016). Age-Related differences in animacy effects as a function of word-order canonicity in a verb-final language: evidence from ERP. Communication Sciences \& Disorders, 21, 653-667.

Osterhout, L., McKinnon, R., Bersick, M., \& Corey, V. (1996). On the language specificity of the brain response to syntactic anomalies: is the syntactic positive shift a member of the P300 family? Journal of Cognitive Neuroscience, 8, 507-526.

Paek, S. H. (2017). Differential effects of age on case marker processing in a verbfinal language (Master's thesis). Ewha Womans University, Seoul, Korea.

Park, T. J. (2004). Cognitive neural mechanisms of aging. Korean Journal of Cognitive and Biological Psychology, 16, 317-336.

Rösler, F., Pechmann, T., Streb, J., Röder, B., \& Hennighausen, E. (1998). Parsing of sentences in a language with varying word order: word-by-word variations of processing demands are revealed by event-related brain potentials. Journal of Memory and Language, 38, 150-176.
Shin, S. I. (2007). A study on the tendency and the factors of word order variations in Korean. Journal of Korean Linguistics, 50, 213-239.

Statistics Korea. (2017). Population projections for provinces: 2015-2045 (based on the 2015 Population Census). Daejeon: Author.

Stine-Morrow, E. A. L., Ryan, S., \& Sandra Leonard, J. (2000). Age differences in on-line syntactic processing. Experimental Aging Research, 26, 315-322.

Stine-Morrow, E. A. L., Shake, M. C., Miles, J. R., Lee, K., Gao, X., \& McConkie, G. (2010). Pay now or pay later: aging and the role of boundary salience in self-regulation of conceptual integration in sentence processing. Psychology and Aging, 25, 168-176.

Sung, J. E. (2015). Effects of syntactic structure on sentence comprehension ability as a function of the canonicity of word-order and its relation to working memory capacity in Korean-speaking elderly adults. Communication Sciences \& Disorders, 20, 24-33.

Tamaoka, K., Sakai, H., Kawahara, J. I., Miyaoka, Y., Lim, H., \& Koizumi, M. (2005). Priority information used for the processing of Japanese sentences: thematic roles, case particles or grammatical functions? Journal of Psycholinguistic Research, 34, 281-332.

Yoon, M. R. (2015). Age-related differences in ERP components associated with Korean passive sentence processing between young and elderly groups (Master's thesis). Ewha Womans University, Seoul, Korea.

Yum, T. H., Park, Y. S., Oh, K. J., Kim, J. K., \& Lee, Y. H. (1992). Korean Wechsler Adult Intelligence Scale (K-WAIS). Seoul: Guidance Korea.

Zurif, E., Swinney, D., Prather, P., Wingfield, A., \& Brownell, H. (1995). The allocation of memory resources during sentence comprehension: evidence from the elderly. Journal of Psycholinguistic Research, 24, 165-182. 


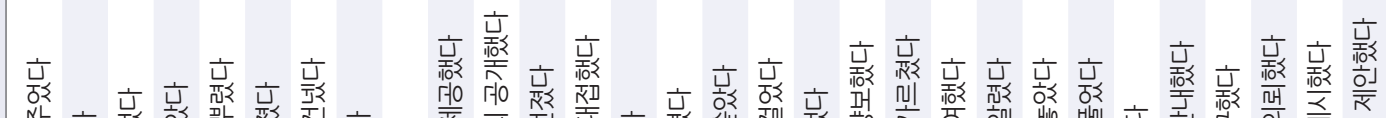

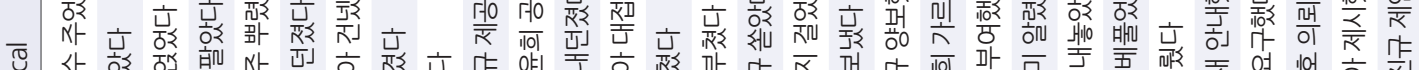

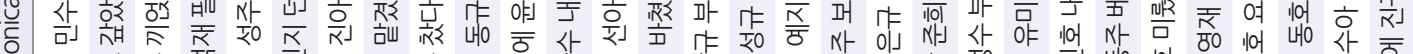

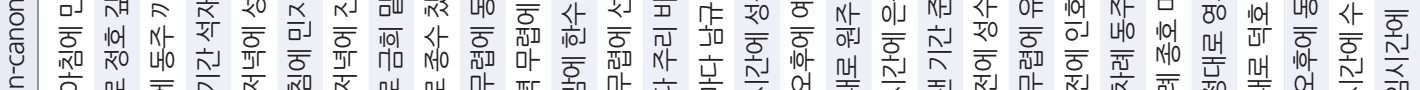

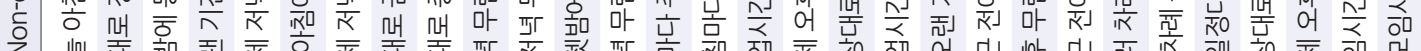

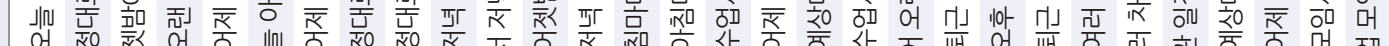

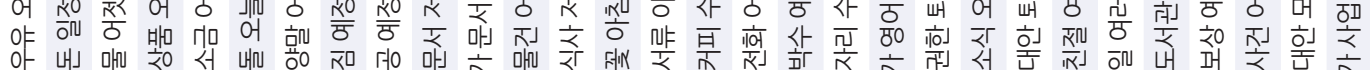

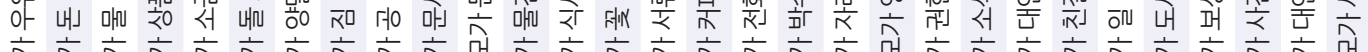

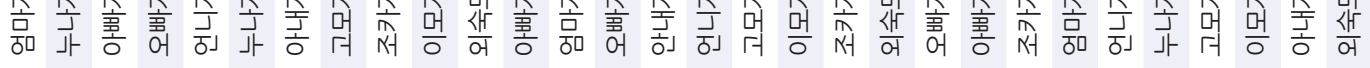

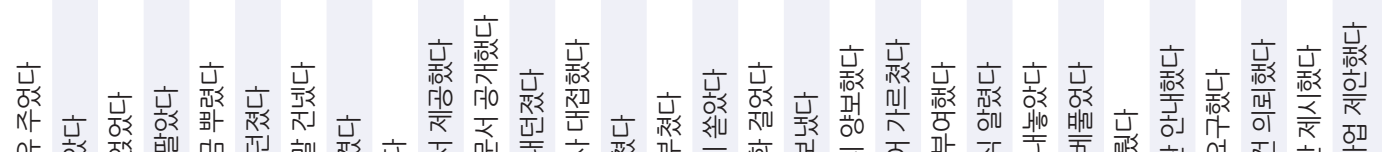
ত্ 次

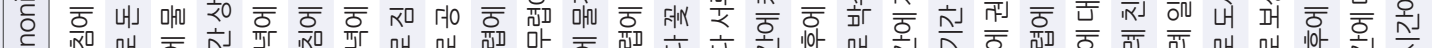

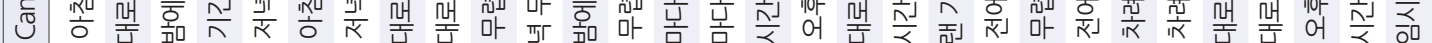

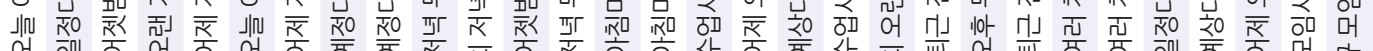

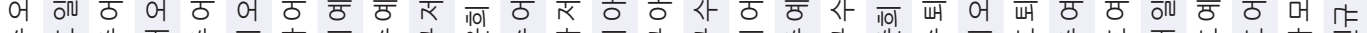

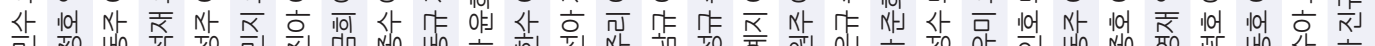

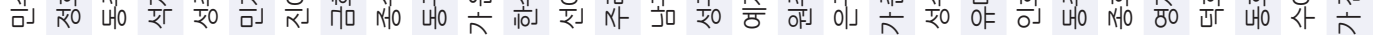

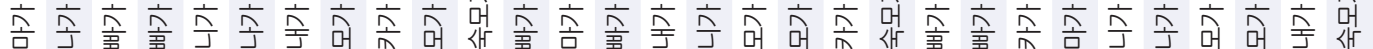

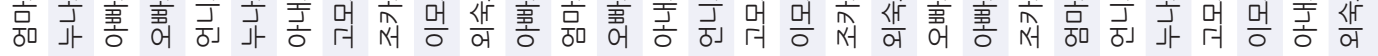

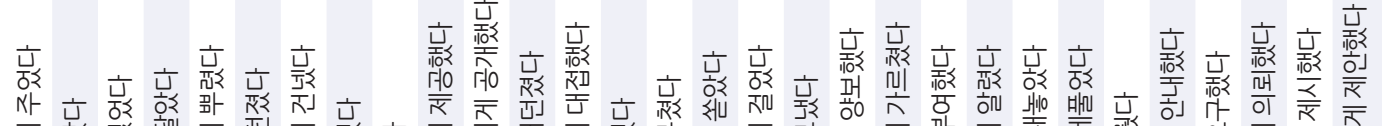

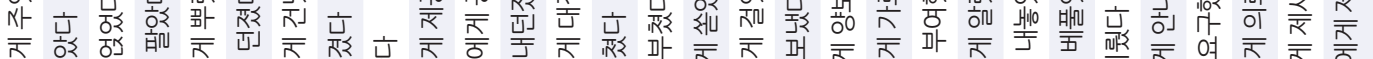

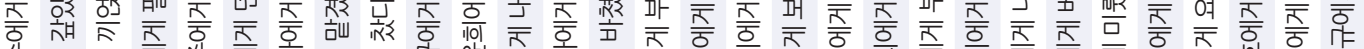

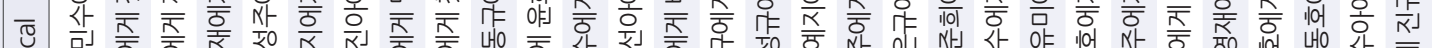

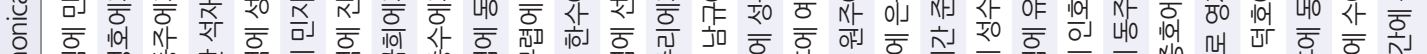

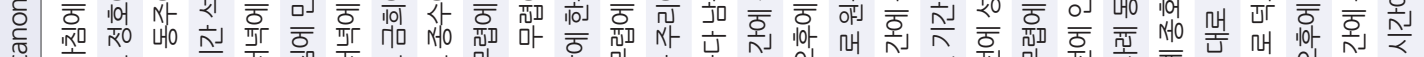

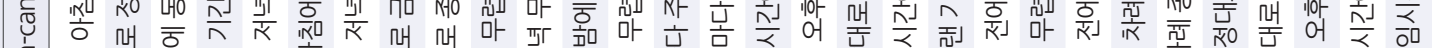

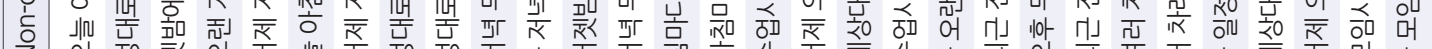

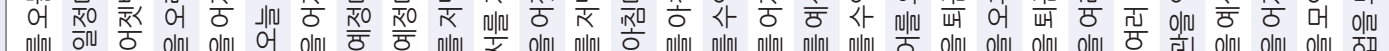
nلw

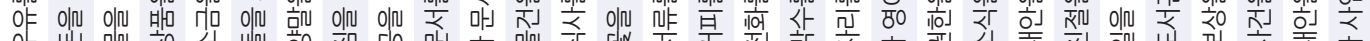

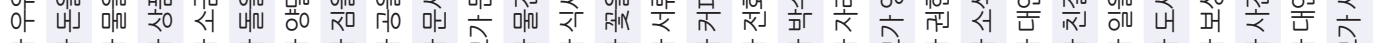

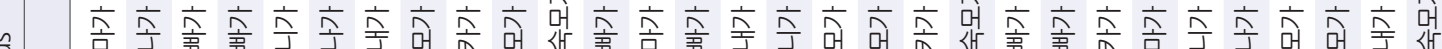

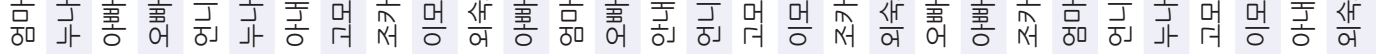

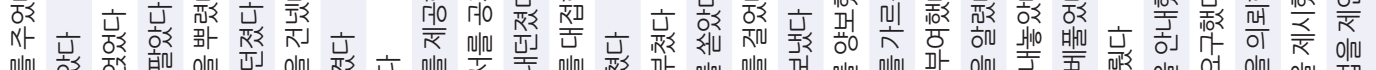
메u额

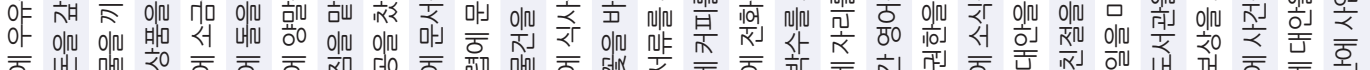
家 너

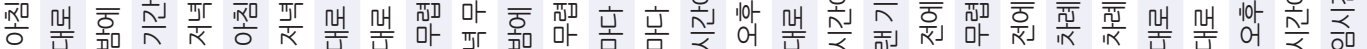

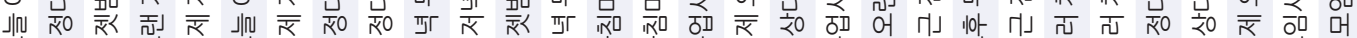

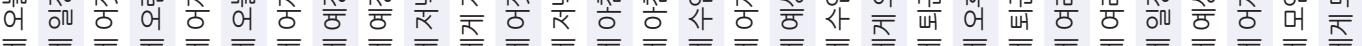

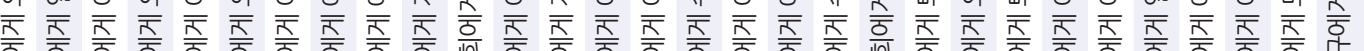

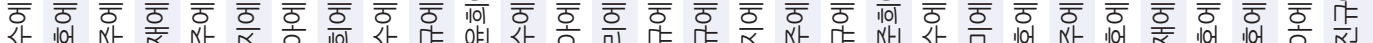

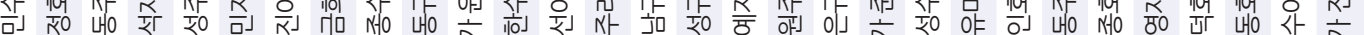

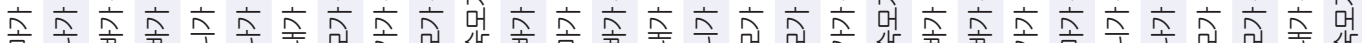

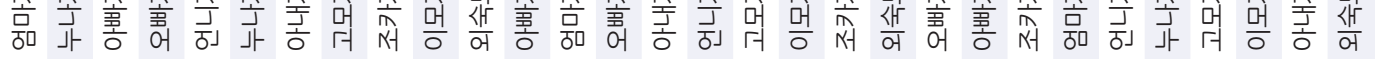




\section{국문초록}

\section{수여동사구문의 통사적 중의성 및 어순전형성에 따른 노년층 대상 ERP 성분 분석 유혜미 · 성지은 \\ 이화여자대학교 언어병리학과}

배경 및 목적: 본 연구는 수여동사구문에서 중의성 여부 및 어순전형성에 따라 문장처리과정에서 청년층과 노년층 간 차이를 사건관 련전위(event-related potential, ERP)를 사용하여 살펴보고자 하였다. 방법: 총 48 명(청년층 24 명, 노년층 24 명)이 참여하였으며, 문장판 단과제 및 온라인 뇌파 분석을 통해 문장처리과정을 살펴보았다. 실험자극은 명사구1 (주어)+명사구2 (여격어/대격어)+부사어+명사 구3 (대격어/여격어)+동사 구조로 5 개의 구(phrase)로 이루어졌다. 어순전형성과 중의성에 따른 조건으로 구분된다. 수여동사구문의 전형적 어순은 여격어 선행이며, 대격어 선행의 경우 비전형 어순에 해당한다. 통사적 중의성은 여격어와 대격어의 격조사를 모두 생략 하여 조작하였다. 이프라임(E-Prime 2.0)과 BrainAmp Standard, actiCAP을 사용하여 행동 데이터 및 뇌파를 기록하였다. 결과: 문장 판단과제 정확도 및 반응시간에서 노년층이 청년층에 비해 유의하게 저조한 수행력을 보였다. 특히, 중의 조건에서 비중의 조건에 비해 더 저조한 수행력을 보였다. ERP 분석결과, 중의 문장의 명사구3에서 청년층은 N400 성분, 노년층은 P600이 관찰되었다. 또한, 청년층 은 중의 문장의 명사구2에서 전형 어순일 때 $\mathrm{P} 300$, 비전형 어순일 때 부적 성분이 출현하였다. 반면, 노년층은 전형 어순과 비전형 어순 에서 유사한 문장처리양상을 보였다. 논의 및 결론: 수여동사구문 문장처리 시 청년층과 노년층의 통사적 중의성 여부와 어순전형성 에 대한 처리양상이 유의하게 다른 양상을 보였다. ERP 분석에서 나타난 연령에 따른 차이는 노화에 따른 문장처리능력 감퇴를 반영 한 것으로 해석된다.

핵심어: 사건관련전위(ERP), 수여동사구문, 통사적 중의성, 어순전형성, 노화, 문장처리

본 논문은 2017년 대한민국 교육부와 한국연구재단의 지원을 받아 수행된 연구임(No. NRF-2017R1A2B4006604).

\section{참고문헌}

강연욱, 나덕렬(2003). 서울신경심리검사(Seoul Neuropsychological Screening Battery). 서울: 휴브알엔씨.

강연욱, 나덕렬, 한승혜(1997). 치매환자들을 대상으로 한 K-MMSE의 타당도연구. 대한신경과학회지, 15, 300-308.

국립국어원(2005). 현대국어사용빈도조사. 서울: 국립국어원.

김동식(2002). 국어 문장의 기본 어순에 관하여. 한신인문학연구, 3, 5-27.

김지인, 성지은, 이수은, 심현섭(2018). 문장 성분 간 거리에 따른 시제 표지 처리 과정에 대한 청년층 및 노년층의 ERP 성분 비교. 언어청각장애연구,

23, 129-145.

박태진(2004). 노화의 인지신경기전. 한국심리학회지 인지 및 생물, 16, 317-336.

백승혜(2017). 문장 내격조사오류에 따른 청년층 및 노년층간 ERP 성분 비교. 이화여자대학교 대학원 석사학위논문.

보건복지부(2012). 제2차 치매관리종합계획. 서울: 보건복지부.

신서인(2007). 한국어의 어순 변이 경향과 그 요인에 대한 연구. 국어학, 50, 213-239.

염태호, 박영숙, 오경자, 김정규, 이영호(1992). 한국판 웩슬러 성인용 지능 검사(K-WAIS): 실시 요강. 서울: 한국가이던스.

오선정, 성지은(2017). 청자-화자 지위관계 및 종결어미 일치 여부에 따라 경어법 문장처리과정에서 나타나는 청년층 및 노년층 간 ERP 성분 차이 분 석. 언어청각장애연구, 22, 101-116.

오세진, 성지은, 심현섭(2016). 한국어 문장처리에서 나타나는 어순전형성에 따른 생물성 효과 연구: 청년층 및 노년층의 ERP 성분 비교 분석. 언어청 각장애연구, 21, 653-667.

윤미류(2015). 한국어 피동형 문장처리과정에서 나타나는 청년층 및 노년층 간 ERP 성분차이 분석. 이화여자대학교 대학원 석사학위논문. 
이미숙, 김향희(2011). 정상 노년층, 경도인지장애, 알츠하이머성 치매의 언어산출 특성. 대한치매학회지, 10, 69-79.

이혜원, 김선경, 이고은, 정유진, 박지윤(2012). 연령에 따른 인지 변화 양상. 한국심리학회지 인지 및 생물, 24, 127-148.

임홍빈(2007). 어순에 관한 언어 유형적 접근과 한국어의 기본 어순. 서강인문논총, 22, 53-120.

전지혜(2016). 주어부의 생물성 여부에 따른 노년층 및 청년층 간 ERP 성분 비교. 이화여자대학교 대학원 석사학위논문.

조은하, 성지은(2018). 관형어 및 동사구 맥락유형에 따라 동음이의어 처리 과정에서 나타나는 청년층 및 노년층 간 ERP 성분 비교. 언어청각장애연

구, 23, 360-377.

통계청(2017). 장래가구추계 시도편: 2015-2045년. 대전: 통계청.

황봉희(2003). 국어 수여동사 구문 연구. 경희대학교 대학원 석사학위논문. 